\title{
25. HIATUS AND TEPHROCHRONOLOGY OF THE ONTONG JAVA PLATEAU: CORRELATION WITH REGIONAL TECTONO-VOLCANIC EVENTS ${ }^{1}$
}

\author{
Loren W. Kroenke, ${ }^{2}$ Johanna M. Resig, ${ }^{2}$ and R. Mark Leckie ${ }^{3}$
}

\begin{abstract}
Evidence of regional tectonism/volcanism in the southwestern Pacific is inferred from the presence of hiatuses and/or ash encountered in the sections drilled on the Ontong Java Plateau at Ocean Drilling Program Sites 803-807 and Deep Sea Drilling Project Sites 288 and 289/586. In general, hiatuses on the plateau do not correlate well with one another or with the deep-sea hiatuses reported by others. Correspondence between groups or clusters of ash horizons between sites on the plateau is better in the upper part of the stratigraphic section than in the lower part. Both hiatus and ash occurrences appear to correlate well with changes in plate motion of the Indo-Australian and Pacific plates, seafloor-spreading history, initiation and cessation of southwest Pacific subduction events, related periods of explosive arc volcanism, and proximal intraplate volcanism.
\end{abstract}

\section{INTRODUCTION}

Many unconformities as well as numerous volcanic ash layers and glass-bearing horizons occur in the deep-sea sedimentary sequences cored at various sites on the Ontong Java Plateau (Fig. 1). The stratigraphic position of the unconformities may denote regional tectonic activity that may have affected the margins of the plateau. The stratigraphic distribution of the ash horizons may reveal the presence of episodes of regional volcanic activity both peripheral to (plate boundary volcanism) and within (intra-plate volcanism) the confines of the Ontong Java Plateau. In this study, we investigate the chronology of hiatuses and ashes and compare the timing of these occurrences to published accounts of regional tectonism to establish whether or not a cause-and-effect relationship may exist between them.

Hiatuses result from denudation of the seafloor either by catastrophic mass movement or mass transport, or by nondeposition or erosion caused by oceanographic bottom-current activity. Kennett (1982) noted that the timing of major changes in the pattern of hiatuses tends to match times of major changes in the configuration of ocean basins that may have caused fundamental changes in circulation. Dissolution may also contribute to the removal of sediment in a carbonate section (Keller and Barron, 1983; Mayer et al., 1986; Theyer et al., 1989). These potential hiatus producers are discussed below.

Tectonism and attendant seismicity has often been cited as the cause of large-scale mass movement and mass transport in the form of submarine landslides (slumps and debris avalanches), debris or mud flows, and turbidity currents (Moore et al., 1989; Tilling et al., 1976). Catastrophic slope failure and large-scale mass transport on the Ontong Java Plateau is evidenced by the presence of a system of large submarine canyons located on the northeast margin of the plateau (Kroenke, 1972; Berger and Johnson, 1976). Berger et al. (1977) suggest that seismicity might be the triggering mechanism for the formation of these large submarine canyons. The southern margin of the Ontong Java Plateau is an area being actively deformed today and one that is characterized by numerous slumps similar to that shown in Figure 2. These slumps, although individually localized,

\footnotetext{
' Berger, W.H.. Kroenke, L.W., Mayer, L.A., et al., 1993. Proc. ODP, Sci. Results, 130: College Station, TX (Ocean Drilling Program).

${ }^{2}$ Department of Geology and Geophysics, School of Ocean and Earth Science and Technology, University of Hawaii, 2525 Correa Road, Honolulu, HI 96822, U.S.A.

${ }^{3}$ Department of Geology and Geography, University of Massachusetts, Amherst, MA 01001, U.S.A.
}

might be expected to be detectable in numerous stratigraphic sections along margins that have undergone tectonic deformation in the past.

Several of the unconformities recognized in drill holes on the Ontong Java Plateau, particularly in upper Paleogene and Neogene strata, may also be related to widespread oceanographic events, including sea-level rises and basin-shelf fractionation of carbonate, global cooling, and intensified bottom water flow, as well as to major changes in the flow paths of currents related to the opening and closing of oceanic gateways (Kennett et al., 1975; Kennett, 1982; Keller and Barron, 1983, 1987; Mayer et al., 1986; Keller et al., 1987; Theyer et al., 1989; Berger et al., 1991). Keller et al. (1987) recognize six widespread Paleogene hiatuses ( $\mathrm{PHa}-\mathrm{PHe}$ ) associated with these events; Keller and Barron (1983, 1987) and Barron et al. (1985) recognize nine widespread Neogene hiatuses (NH1a-NH8) in the Miocene-basal Pliocene deep-sea record.

Paleoceanographic events have had a profound effect on sedimentation rates determined on the Ontong Java Plateau (see, e.g., Berger et al., 1991), but it is not clear that they are solely, or even partially responsible, for the hiatuses observed in the sedimentary sections drilled on the plateau.

Volcanic ash/glass may be produced in either the subaerial or submarine environment, mostly by island-arc and continental-margin volcanism at convergent boundaries (Kennett, 1981); also by intraplate volcanism over hotspots; and, to a lesser degree, by spreadingridge volcanism at divergent boundaries. Consequently, the presence of fresh ash or glass in a stratigraphic section may be viewed as evidence of the occurrence of one or more of these types of volcanism. Kennett et al. (1977) concluded that the stratigraphic distribution of volcanic ash horizons in deep-sea sedimentary sequences provides a reliable means of detecting episodes of explosive Neogene volcanism. They also concluded that although plate motions, diagenetic alteration of volcanic ash layers, and changing intensity of global winds all influence to some degree the distribution of ash layers in deep-sea sedimentary sequences, these effects, when considered over wide regions, are less important than the influence of volcanic episodicity itself. Rea and Vallier (1983), in discussing two episodes of Cretaceous intraplate volcanism in the western Pacific Ocean, noted that most ash is deposited within $500-1000 \mathrm{~km}$ of the source and that only the largest eruptions result in deep-sea ash layers at greater distances. In contrast, explosive arc volcanism can disperse fine-grained ash many thousands of kilometers from the site of the eruption (see, e.g., Kyle and Seward, 1984). However, the presence of coarse-grained ash, particularly in large quantities, is taken as evidence of a nearby provenance. 


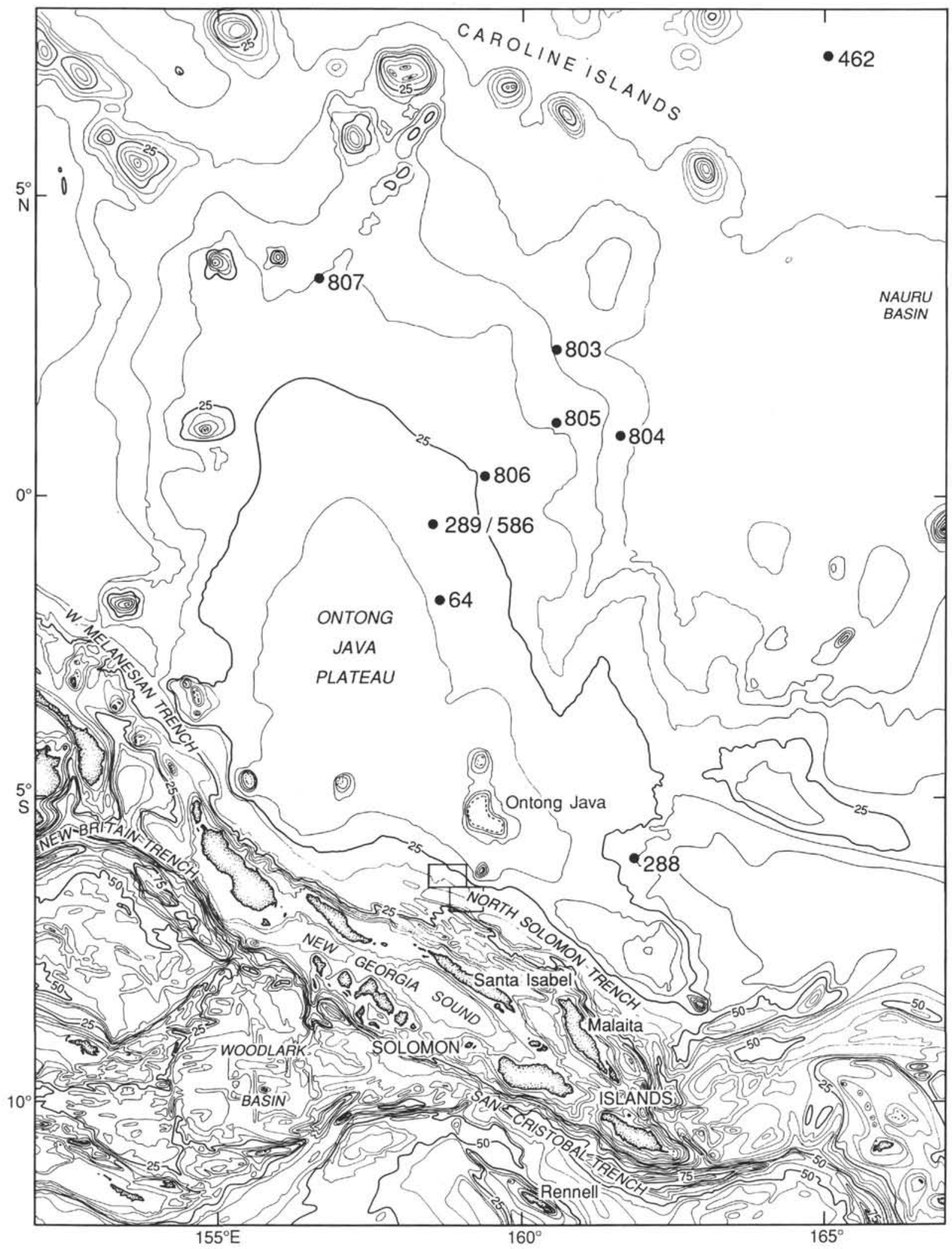

Figure 1. Locations of DSDP and ODP drill sites on the Ontong Java Plateau. Box indicates location of slump scars shown in Figure 2. 


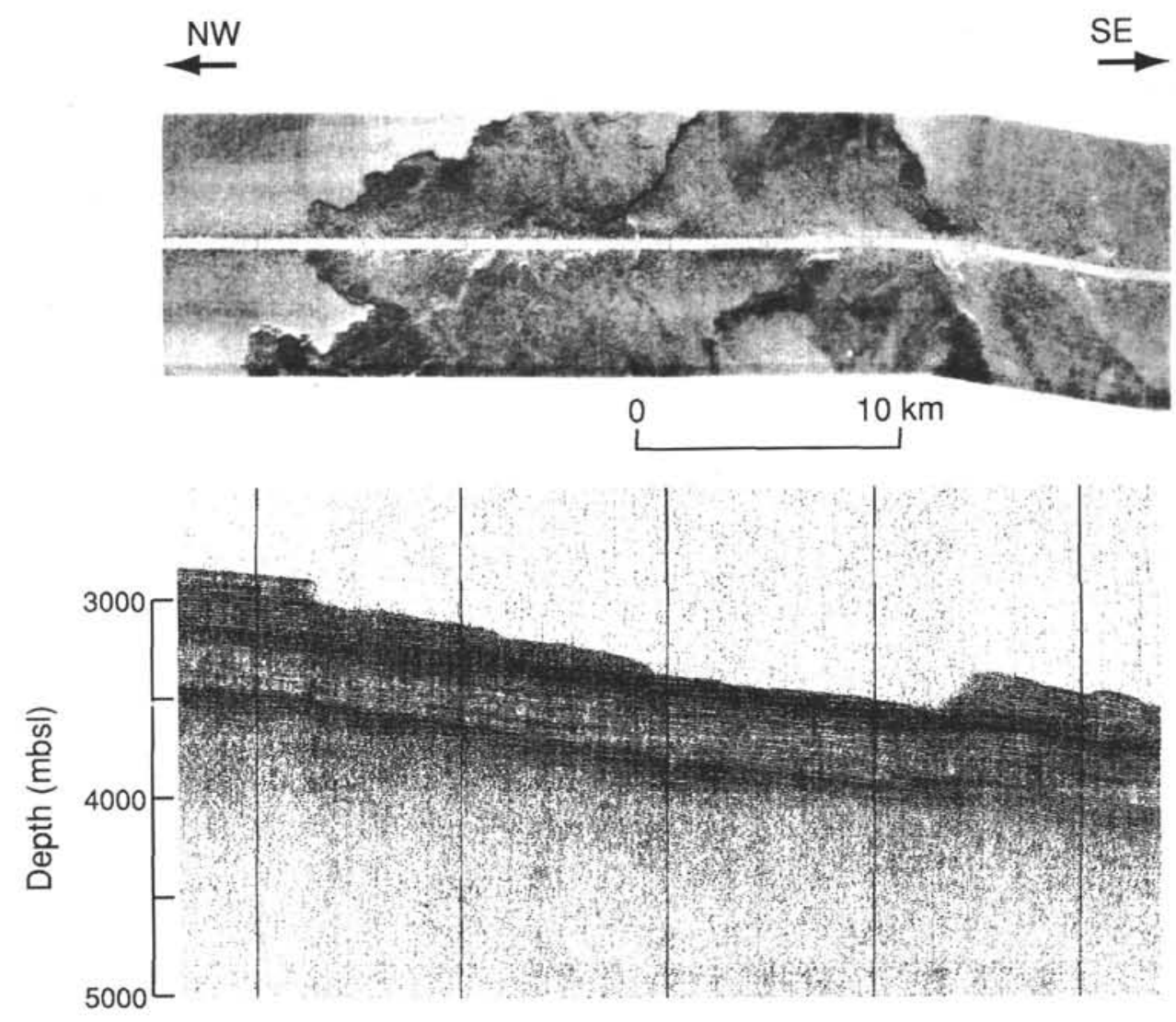

Figure 2. Sys09 side-scan image and single-channel seismic reflection profile across a recent, major slump scar on the southern margin of the Ontong Java Plateau. The $9-\mathrm{kHz}$ image and reflection profile provided by Seafloor Surveys International and used with permission of OTC Ltd., Australia.

The fact that ash commonly occurs in apparent association with hiatuses lends credence to the assumption of a genetic relationship between the hiatuses and tectonism. Thus, we have inferred regional volcanic/tectonic events in the southwest Pacific based on the presence of ash and/or hiatuses encountered in the sections drilled and cored to date on the Ontong Java Plateau.

Eight sites have been drilled on the Ontong Java Plateau (Fig. 1) since the beginning of scientific deep ocean drilling. Five of these sites (ODP Sites 803 and 807 and DSDP Sites 64, 288, and 289) were rotary cored to considerable depth and, collectively, provide an almost complete sedimentary record since the early Aptian. DSDP Site 64 (Winterer, Riedel, et al., 1971) was spot cored at widely spaced intervals and therefore is not included in this discussion. DSDP Site 288 (Andrews, Packham, et al., 1975) was spot cored at more closely spaced intervals down to 988.5 mbsf, reaching Aptian cherty limestones at the bottom of the hole. The remaining sites on the Ontong Java Plateau were continuously cored. ODP Sites 803 and 807 reached upper Cenomanian brown clay and lower Aptian limestone, respectively (Kroenke, Berger, Janecek, et al., 1991), and DSDP Site 289 reached upper Aptian limestone before penetrating basalt flows. Although DSDP Sites 586 and 289, which are about $4 \mathrm{~km}$ apart, are essentially the same site, they are considered separately to facilitate comparison. DSDP Site 586 was cored with the hydraulic piston corer (HPC) to $300 \mathrm{mbsf}$, reaching the lowest upper Miocene (Moberly, Schlanger, et al., 1986; Kennett, von der Borch, et al., 1986). Sites $803-807$ were triple cored with the advanced hydraulic piston corer (APC) to the objective horizon and then cored with the extended core barrel (XCB) to refusal, reaching the middle Eocene at Site 803 (before rotary coring) and Oligocene at Sites 804-806; Site 807 was double APC cored and then XCB cored to Oligocene (before rotary coring). The HPC/APC-XCB cored sites have the best recovery and thus provide the highest resolution.

\section{METHODS}

\section{Approach to the Problem}

In evaluating the potential effect of regional tectonism on the sedimentary section preserved at each drill site, the relative stability of each location was taken into consideration. For example, ODP Sites 805,806 , and 807 and DSDP Sites $289 / 586$ are situated on the stable interior of the high plateau, whereas ODP Sites 803 and 804 are located along the less stable northeastern flank of the high plateau and DSDP Site 288 is downslope from its intensely faulted eastern edge (see site report in Andrews, Packham, et al., 1975). These less stable sites are probably more susceptible to mass wasting caused by regional tectonic events and thus are considered to be better indicators of the events.

We have also presumed that the timing of the occurrence of the tectonic event is indicated by the age of the sediment found at the top of the hiatus, which most likely represents the time of resumption of sediment accumulation at the end of tectonic activity. However, the length of time embraced by the hiatus may have no bearing on the duration of the tectonic event, the time gap simply reflecting the intensity of the tectonic event or the degree of slope instability. Furthermore, a single hiatus may comprise more than one tectonic event.

Volcanic events were identified based on the presence of visible layers or beds of ash in the cores and/or recognizable quantities of volcanic glass in the smear slides taken from the cores. Ash layers, particularly if the ash is coarse grained, are considered to indicate the 
proximity of the site to the volcanism. Minor amounts of fine-grained volcanic glass/ash, as determined by shipboard smear slide examination, are taken to indicate distal volcanic activity. However, the presence of detectable amounts of ash at one drill site/hole and the absence at another may only signify that the identical stratigraphic horizon was not sampled at both drill sites/holes.

\section{Chronostratigraphic Control}

Time scales used in establishing the chronology of the ash and hiatus events in the Ontong Java Plateau section are as follows:

Pleistocene-Miocene: Berggren et al., 1985b;

Oligocene-Eocene: Berggren et al., 1985a;

Paleocene: Harland et al., 1990; and

Cretaceous: Harland et al., 1982.

The Berggren et al. (1985a, 1985b) time scales, as well as the first and last appearance events of various microfossil species, were used in developing shipboard sedimentation rates for the Leg 130 sites, from which the hiatus and ash dates could be derived. Because recent radiometric $\mathrm{Ar}$ dates indicate a $64.5 \pm 0.1 \mathrm{~m} . \mathrm{y}$. age for the Cretaceous/Tertiary (K/T) boundary (Izett et al., 1991), which is about 2 m.y. younger than the boundary in Berggren et al. (1985a), the Harland et al. (1990) scale was substituted for the Paleocene as being more compatible with the radiometric dates. The Harland et al. (1982) scale for the Cretaceous is used following Sliter (1989), whose foraminiferal stratigraphy dates the Mesozoic parts of the section (Sliter, in press; Sliter and Leckie, this volume).

Detailed foraminiferal stratigraphy is not available for DSDPSites 288 and 289; therefore, in correlating stratigraphies between these and subsequent sites, the nannofossil zonation used by Shafik (1975) was related to Martini's $(1970,1971)$ zones and the Berggren et al. (1985a, 1985b) time scales (Appendix A). Martini's zones were also used in the stratigraphy of Site 586. For Sites 288 and 289, age (Ma) was assigned to boundaries or approximate boundaries of the various units depending upon the continuity of coring, and ages were assigned the various ash events through extrapolation, under assumption of uniform sediment accumulation rates between dated horizons. For Sites 803-807, the ash event dates were derived from sediment accumulation rate diagrams based on foraminiferal and nannofossil first and last appearance datums (Kroenke, Berger, Janecek, et al., 1991). At all sites, hiatus duration was based on the length of missing fossil datums or biostratigraphic zones.

\section{Data}

Hiatuses, recognized through missing biostratigraphic zones, are documented for Sites 288 and 289 through the Tertiary nannofossil stratigraphy of Shafik (1975) and the Cretaceous foraminiferal stratigraphy of Sliter (in press). Hiatuses at Sites 803, 804, and 807 are based on the combined foraminiferal and nannofossil zonal and event stratigraphy given in the site chapters of the Leg 130 Initial Reports volume (Kroenke, Berger, Janecek, et al., 1991), except for the Cretaceous and Paleocene of Site 807, where the hiatuses are documented through the foraminiferal stratigraphy of Premoli Silva and Sliter (this volume) and Sliter and Leckie (this volume). The sources of hiatus data as well as their chronostratigraphic position are given in Appendix B and shown on Figure 3.

The regional hiatuses of Keller et al. (1987) and Keller and Barron (1987) are shown for comparison on Figure 3. These regional hiatuses have been attributed by Haq (1991) to alternating erosive/corrosive response to sea-level fall and rise. Haq's (1991) classification of dissolution and erosional hiatuses, after Keller and Barron (1987), is also shown on Figure 3. Haq noted that dissolutional gaps are usually of shorter duration than erosional hiatuses, which are difficult to date because their time of initiation is unknown.
In Figure 3, condensed sections at Sites 805, 806, and 807 appear to correlate with dissolution Hiatus NHIb and could be contained within the hiatus of longer duration at Sites 803 and 804 . However, no indication of this hiatus is present at Site 289, which is the shallowest site drilled to date on the Ontong Java Plateau. Although Barron et al. (1985) report a short hiatus at 12-11.5 Ma (NH3) and reduced sedimentation rates at $18.7-16.3(\mathrm{NH} 1 \mathrm{~b})$ and $10.9-6.4 \mathrm{Ma}$ (NH5-6) at DSDP Site 289, J.A. Barron (pers. comm., 1992) no longer considers the hiatus to be present but suggests that two short condensed sections might occur at 5.0-5.5 and 7.5-8.0 Ma. In the HPC-cored holes at DSDP Site 586 within $4 \mathrm{~km}$ of Site 289 , a downhole replot of microfossil events, according to the time scale of Berggren et al. (1985b), shows no presence of a hiatus or condensed section. Barron et al. (1985) suggest that shallow sites such as Site 289 were above most of the bottom currents and corrosion that causes many of the deep-sea hiatuses.

The condensed section near the top of ODP Site 804, which appears to correlate with dissolution Hiatus $\mathrm{NH} 7$, coincides with the top of a slump block whose base is bounded by the aforementioned long-duration (20-15 Ma) hiatus (see fig. 38 in Kroenke, Berger, Janecek, et al., 1991). Both the condensed section and the hiatus most likely are the result of local slumping and not an oceanographic event. The upper of the two condensed sections at DSDP Site 289 also appears to correlate with Hiatus NH7. The lower condensed section, however, appears to fall between two erosional events, NH5 and NH6. These condensed sections were not found at DSDP Site 586, nearby, nor were they encountered at ODP Sites $803,805,806$, and 807 .

In general, hiatuses on the Ontong Java Plateau do not correlate well with one another or with the regional hiatuses of Keller et al. (1987) and Keller and Barron (1987). Hiatuses are more frequent at DSDP Site 288 on the eastern salient of the Ontong Java Plateau than at the other sites on the northeastern margin. In fact, the section cored at DSDP Site 288 is so riddled with hiatuses that if this site alone is considered, correlation with any or all of the Neogene (but not the Paleogene) hiatuses is possible. It is interesting to note that of all the possible Neogene paleoceanographic hiatuses that might be represented at DSDP Site 288 only one (NH1b) was found to occur at ODP Site 805 , which is located in deeper and potentially more corrosive water. Likewise, of all the Paleogene paleoceanographic hiatuses that might be represented at Site 288, none were found to occur at ODP Site 803 , which is located in still deeper water. The only commonality that seems to hold is the location of DSDP Site 288 and ODPSites 803 and 804 close to the potentially more unstable eastern margin of the high plateau. Considerable downslope transport is evident in reflection profiles across Site 288 (see figs. 3 and 5, DSDP Site 288, in Andrews, Packham, et al., 1975), suggesting that most of the hiatuses at this site may be the result of erosion or mass wasting.

The occurrences of ash layers and traces of ash (Appendix C) were derived primarily from the core description sheets for each site and secondarily from the site chapters of the initial reports. After an age had been assigned for each occurrence, their positions were entered on a diagram (Fig. 4) showing their chronostratigraphic relationship between sites. Trace occurrences of $<1 \%$ are indicated by dashed lines on the diagram for Sites 586 and 803 807 , whereas dashed lines for Holes 288 and 289 indicate occurrences of $<2 \%$. Little chance exists that these low occurrences were consistently sampled from site to site, but clusters of trace occurrences are indicative of persistent volcanism.

The chronostratigraphic positions of all reported ash occurrences in the holes drilled on the Ontong Java Plateau are shown in Figure 4. Periods of island-arc volcanism and other tectono-volcanic events occurring within the region (Kroenke, 1984) as well as episodes of increased volcanic activity (Kennett and Thunell, 1975; Kennett et al., 1977, 1985; Rea and Vallier, 1983) are shown for comparison. Within the four periods of arc volcanism that span the Eocene, Oligocene, early to middle Miocene, and the middle Miocene to Holocene, episodes or pulses of volcanism occur during the Aptian 


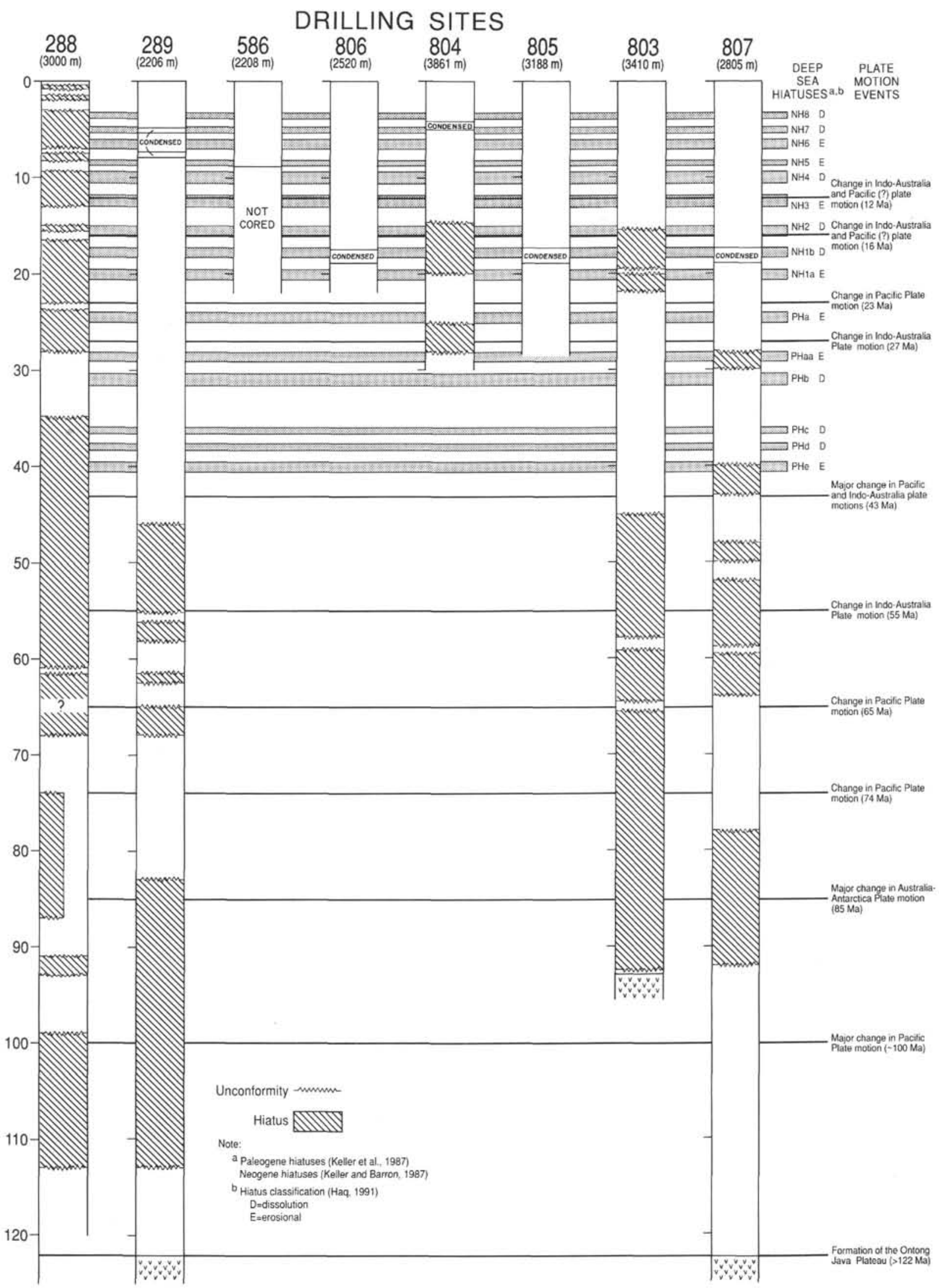

Figure 3. Stratigraphic occurrences of unconformities (depicting hiatus duration) at drill sites on the Ontong Java Plateau, shown with deep-sea hiatuses and timing of changes in plate motion. Water depth at each site (meters below sea level) is given in parenthesis below each site number. 


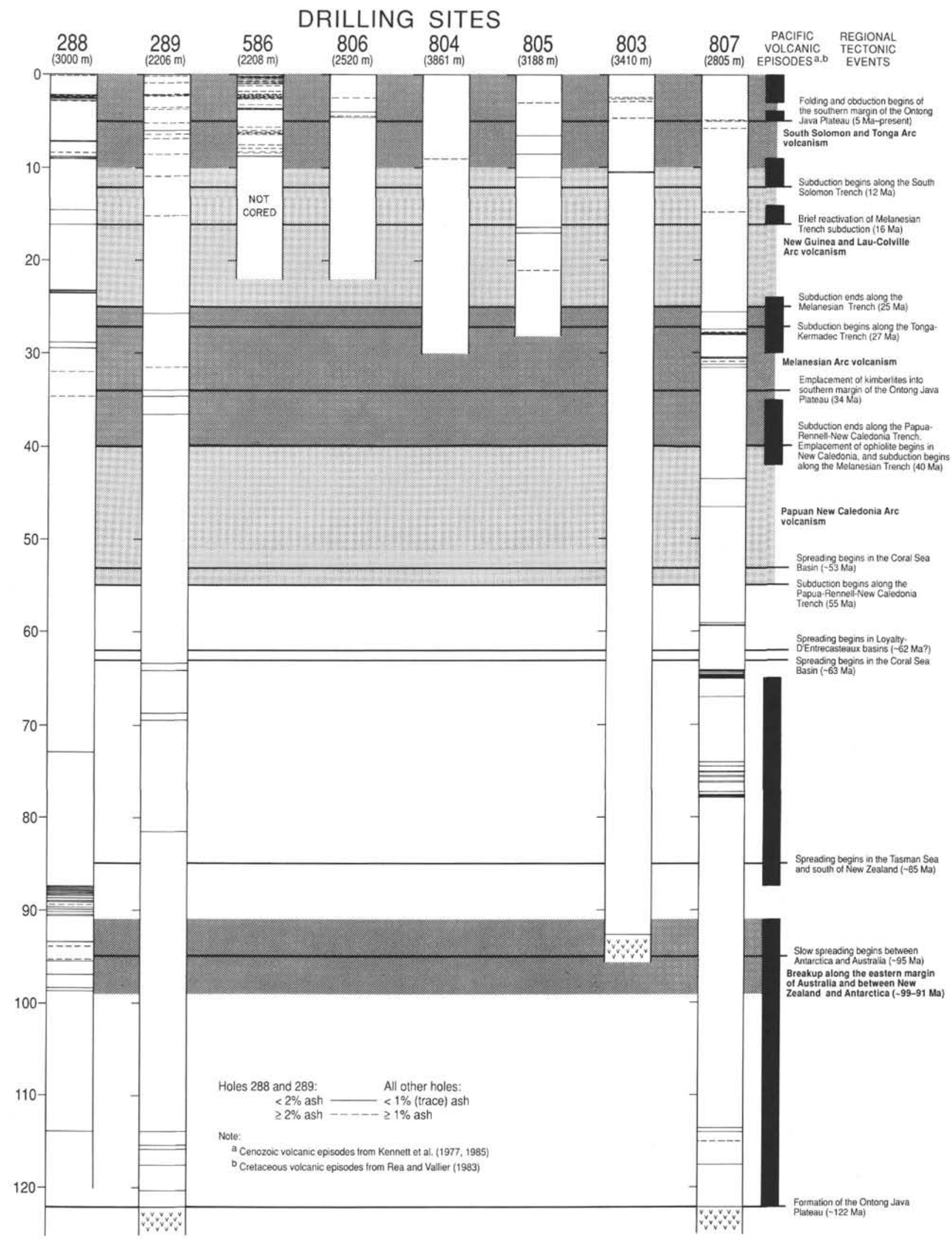

Figure 4. Stratigraphic occurrences of ash at drill sites on the Ontong Java Plateau, shown with periods of arc volcanism, Pacific volcanic episodes, and other regional tectono-volcanic events. 
to Cenomanian, Santonian to Maastrichtian, late early Oligocene, late Oligocene, middle Miocene, late Miocene, early Pliocene, and the Quaternary. These occurrences may provide insight into the origin of some of the ash layers found on the plateau.

Ash horizons are more frequent in the upper part of the section where clusters of ash horizons generally correspond from site to site. The sparse occurrence of ash in the four deep holes and the frequent lack of obvious correlation from site to site is probably a reflection of the presence of hiatuses (Fig. 3) rather than the absence of volcanism or a discontinuous depositional pattern. Nevertheless, considerable information can be extrapolated from the ash layers that are present. In general, clusters of ash occurrences show a better relationship to the longer periods of arc volcanism in the Cenozoic than to the shorter episodes or pulses of volcanism reported by Kennett et al. (1977) for the same time span (Fig. 4). Cretaceous ash occurrences on the Ontong Java Plateau correspond fairly well with the two episodes of Cretaceous volcanism reported by Rea and Vallier (1983). The apparent lack of correspondence of the Turonian ash at DSDP Site 288 with the older of the two episodes is probably an artifact of revision of the time scale and extrapolation of the ages of the ashes at Site 288, based on our revised sediment accumulation rates.

Extrusive basalt flows were cored at DSDP Site 289 (Andrews, Packham, et al., 1975) and ODP Sites 803 and 807 (Kroenke, Berger, Janecek, et al., 1991). These basalts have been dated by ${ }^{39} \mathrm{Ar} /{ }^{40} \mathrm{Ar}$ at $122 \mathrm{Ma}$ for ODP Site 807 and DSDP Site 289 and $90 \mathrm{Ma}$ (or $93 \mathrm{Ma}$ based on the age of plagioclase separates) for ODPSite 803 (Mahoney et al., this volume). Volcanic basement associated with the formation of the Ontong Java Plateau was drilled only at DSDP Site 289 and ODP Site 807 . Ash was found overlying basement only at Site 289, and although it is plotted at an extrapolated age of $120.5 \mathrm{Ma}$ (Fig. 4), it may in fact be the same age as basement.

Regional tectonic events for the Cretaceous and Tertiary (Kroenke, 1984; Duncan and McDougall, 1989) as well as changes in plate motion (Duncan, 1981, 1991; Duncan and Clague, 1985; Epp, 1978, 1984; Yan, 1988), are summarized in Table 1. To facilitate discussion, the tectonic and stratigraphic information is integrated in Figure 5.

\section{DISCUSSION}

Based on the present-day location of the plateau in juxtaposition with the Nauru Basin M-series magnetic anomaly lineations (Larson, 1976) and the age of the plateau basement basalts at ODP Site 807 and DSDP Site 289, formation of the Ontong Java Plateau must have begun close to or along the southern margin of the Pacific Plate before $122 \mathrm{Ma}$. The plateau, at this time, probably was forming over a hotspot along or near a spreading ridge at the southern margin of the Pacific Plate. Mahoney (this volume) reports that Ontong Java lavas appear to represent very high degree melts, consistent with a near-ridge origin for the plateau. The thick ash beds that overlie basement at DSDP Site 289 (Appendix C), as well as the minor amounts of ash present during this same time span at DSDP Site 288 and ODP Site 807 (Fig. 5), may indicate a continuation of plateau formation along this ridge system to $117 \mathrm{Ma}$.

An Albian hiatus, beginning approximately at $113 \mathrm{Ma}$ and extending to approximately $99 \mathrm{Ma}$, is present at DSDP Site 288. An ash layer occurs immediately above the hiatus. The end of this hiatus coincides with a major northward change in Pacific Plate motion at $100 \mathrm{Ma}$ (Duncan and Clague, 1985; Leg 129 Scientific Drilling Party, 1990) and may indicate tectonic activity accompanying this change in plate motion. This same time span is embraced by a hiatus of much greater duration (Albian-Campanian) at DSDP Site 289 and might well be incorporated within it. No evidence for this hiatus is present at ODP Site 807 , which lies well within the stable interior of the plateau. Sill intrusions, however, that occurred about the same time far to the northeast of the Ontong Java Plateau at DSDP Site 462 (Schlanger and Moberly, 1986) also may be a consequence of this same event.
Regional tectonism also may be responsible for at least some of the ash above the Albian hiatus and below a Cenomanian hiatus at DSDP Site 288. In Albian through Cenomanian time, the Ontong Java Plateau was located far to the southeast of its present position (see Yan and Kroenke, this volume). During this same time span, slow spreading occurred between Australia and Antarctica (Cande and Mutter, 1982; Cande et al., 1989) and breakup was in progress in the Tasman Sea along the eastern margin of Australia (Shaw, 1979) as well as between New Zealand and Antarctica, south of the Campbell Plateau (Duncan and McDougall, 1989). Although the upper level wind pattern is that of prevailing westerlies, small quantities of ash produced by volcanism related to the breakup event or by arc volcanism in Fiordland, New Zealand (Mattinson et al., 1986) may have been blown northward into the vicinity of DSDP Site 288 by largeamplitude baroclinic waves. In contrast, ODP Site 807 during this time would have been located almost $10^{\circ}$ farther to the north, perhaps outside of the depositional plumes from these events.

The Cenomanian hiatus at DSDP Site 288 begins approximately at $93 \mathrm{Ma}$ and extends to approximately $91 \mathrm{Ma}$. This time gap occurs in the lower part of a rhythmic, graded limestone/ash sequence (Fig. 5 and Appendix C) interpreted to be turbidites (Klein, 1975) that most likely originated nearby on the high plateau, upslope from Site 288. Although evidence for tectono-volcanic activity is missing at Site 289, concealed, perhaps, by the long-ranging Aptian-Campanian hiatus, it may be manifest at ODP Site 803 as the "basement" basalt flows that were cored there. Those basalt flows, dated at $90 \mathrm{Ma}$ (93 Ma if only the age of the plagioclase separates is believed), are only slightly older than the main influx of turbiditic ash deposits, which occurred between 88.5 and $87.5 \mathrm{Ma}$, above the hiatus at Site 288. Albeit slight, this difference in age is in accord with a volcanic age progression south-southeastward across the plateau, which, in turn, suggests a hotspot source for this volcanism. Between 93 and $87 \mathrm{Ma}$, the plateau would have been following a north-northwestward trajectory (Duncan and Clague, 1985). Thus, diffuse volcanism may have migrated from north to south across the Ontong Java Plateau as the plateau passed over the hotspot. Flows would have spread out from and along the fractured boundary between the high plateau and the eastern salient, perhaps in similar fashion to the diffuse style of volcanism produced when the Mendocino and Murray fracture zones passed over the Hawaiian hotspot (Epp, 1984).

At DSDP Site 289, the top of the long-ranging Aptian-Santonian hiatus ( $83 \mathrm{Ma})$, overlain by a small quantity of ash, comes after a major change in Indo-Australian plate motion and roughly coincides with the beginning of fast spreading south of New Zealand (Molnar et al., 1975; Cande et al., 1989) and within the Tasman Basin (Shaw, 1979). Tectonism associated with these events may well have affected the Ontong Java Plateau. The timing of this tectonic activity cannot be confirmed elsewhere on the plateau, however, because its effect would be concealed within the long-ranging hiatuses found at the other sites.

The top of a possible upper Santonian-Campanian hiatus (74 Ma) at DSDP Site 288, which is also overlain by a small quantity of ash, coincides with a change in Pacific Plate motion at that time. If this hiatus does exist, it may be related to that event. Lack of evidence of this hiatus at DSDP Site 289 may simply reflect the site's more stable position on the high plateau. The timing of this event cannot be confirmed at ODP Site 803 because it is concealed within the longranging hiatus that occurred there. The top of the upper Cenomanianmiddle Campanian hiatus at ODP Site 807 is also poorly constrained and therefore might be as young as $74 \mathrm{Ma}$ (uppermost Campanian). However, the numerous relatively coarse-grained ash layers overlying the hiatus at this site (Appendix $\mathrm{C}$ and Fig. 5) suggest nearby volcanic activity. The source of the volcanism most likely was a hotspot, as the site was quite distant from any known plate boundary at this time.

Both the top of the upper Maastrichtian hiatus at DSDP Site 289 and the top of the upper Cenomanian-Maastrichtian hiatus at ODP 
Table 1. Regional tectonic events.

\begin{tabular}{|c|c|c|}
\hline Chron & $\begin{array}{l}\text { Age } \\
(\mathrm{Ma})\end{array}$ & Event \\
\hline $34 \mathrm{~N}$ & 100 & Major change in Pacific Plate motion. \\
\hline $34 \mathrm{~N}$ & 95 & Australia-Antarctica slow spreading begins. \\
\hline $33 R$ & 85 & $\begin{array}{l}\text { Major change in Australia-Antarctica Plate motions. } \\
\text { Spreading begins in the Tasman Basin and south of the Campbell Plateau (Cande et al., 1989). }\end{array}$ \\
\hline $33 \mathrm{~N}$ & 74 & $\begin{array}{l}\text { Change in Pacific Plate motion. } \\
\text { New Caledonia Basin spreading begins. }\end{array}$ \\
\hline 29 & 65 & $\begin{array}{l}\text { Change in Pacific Plate motion. } \\
\text { New Caledonia Basin spreading ends. }\end{array}$ \\
\hline 27 & 63 & Coral Sea Basin spreading begins. \\
\hline 24 & 55 & $\begin{array}{l}\text { Major change in Indo-Australia Plate motion. } \\
\text { Tasman Basin spreading ends. } \\
\text { Papuan-New Caledonia-Norfolk subduction begins. }\end{array}$ \\
\hline 24 & 53 & $\begin{array}{l}\text { Coral Sea Basin spreading ends. } \\
\text { Papuan-New Caledonia-Norfolk Arc volcanism begins. }\end{array}$ \\
\hline 19 & 43 & $\begin{array}{l}\text { Major change in Pacific and Indo-Australia Plate motions. } \\
\text { Melanesian (North Solomon Island-Vitiaz) subduction begins. }\end{array}$ \\
\hline & 40 & $\begin{array}{l}\text { Papuan-New Caledonia-Norfolk subduction ends. } \\
\text { Melanesian (West Melanesian-North Solomon Island-Vitiaz) Arc volcanism begins. }\end{array}$ \\
\hline 12 & 34 & $\begin{array}{l}\text { South Fiji Basin spreading begins. } \\
\text { Three Kings-Northland subduction begins. } \\
\text { Emplacement of kimberlites into the southern margin of the Ontong Java Plateau. }\end{array}$ \\
\hline & 32 & Three Kings Arc volcanism begins. \\
\hline 8 & 27 & $\begin{array}{l}\text { Change in Indo-Australia Plate motion. } \\
\text { New Guinea (Wewak-Trobriand) subduction begins. } \\
\text { Tonga-Kermadec subduction begins. }\end{array}$ \\
\hline 7 & 25 & $\begin{array}{l}\text { South Fiji Basin spreading ends. } \\
\text { Three Kings-Northland subduction ends. } \\
\text { Melanesian (West Melanesian-North Solomon Island-Vitiaz) subduction ends. } \\
\text { Lau-Colville (proto-Tonga) Arc volcanism begins. }\end{array}$ \\
\hline 6 & 23 & $\begin{array}{l}\text { Change in Pacific Plate motion. } \\
\text { Change in Indo-Australia Plate motion. } \\
\text { Brief reactivation of Melanesian subduction. }\end{array}$ \\
\hline & 12 & $\begin{array}{l}\text { Change in Indo-Australian Plate motion. } \\
\text { South Solomon (New Britain, San Cristobal, New Hebrides) subduction begins. }\end{array}$ \\
\hline $5 \mathrm{~N}$ & 10 & $\begin{array}{l}\text { South Solomon Arc volcanism begins. } \\
\text { North Fiji Basin spreading begins. } \\
\text { New Guinea (Wewak-Trobriand) subduction ends. }\end{array}$ \\
\hline & 5 & Folding and obduction begins along the southern margin of the Ontong Java Plateau. \\
\hline
\end{tabular}

Site 803 occur just below the K/T boundary ( $64.5 \mathrm{Ma}$; cf. Izett et al., 1991), which is also about the time of a change in Pacific Plate motion (Duncan and Clague, 1985). Coincidentally, this is also about the time when numerous thin layers of ash began to accumulate at ODP Site 807 . Zeolites, which are probably altered ash, occur above and below the $\mathrm{K} / \mathrm{T}$ boundary at DSDP Site 289 (Appendix C and Fig. 5). This part of the section (i.e., the interval containing the K/T boundary) was not cored at DSDP Site 288. About this same time, spreading ceased in the New Caledonia Basin (Kroenke, 1984) and spreading was about to start in the Coral Sea Basin (Weissel and Watts, 1979), both of which may have been accompanied by widespread tectonism. The location of these basins, as well as those that are discussed below, are shown in Figure 6.
The top of the middle Maastrichtian/upper Paleocene hiatus at DSDP Site 288 and the top of the Paleocene hiatus at DSDP Site 289, which occurred about $62 \mathrm{Ma}$, may be associated with the initiation of spreading in the Coral Sea Basin (Weissel and Watts, 1979) and perhaps the Loyalty and D'Entrecasteaux basins that lie northeast of New Caledonia and southwest of the Ontong Java Plateau. At ODP Sites 803 and 807 , this event may be concealed within the more extensive hiatuses found there. Although these hiatuses might be caused entirely or in part by oceanographic events, the time span of 65-43 Ma was characterized by extensive plate reorganization and intensive regional tectonic activity. The top of the upper Paleocenelower Eocene hiatus at DSDP Site 289 is very close to the time of a pronounced change in Indo-Australia Plate motion that occurred 


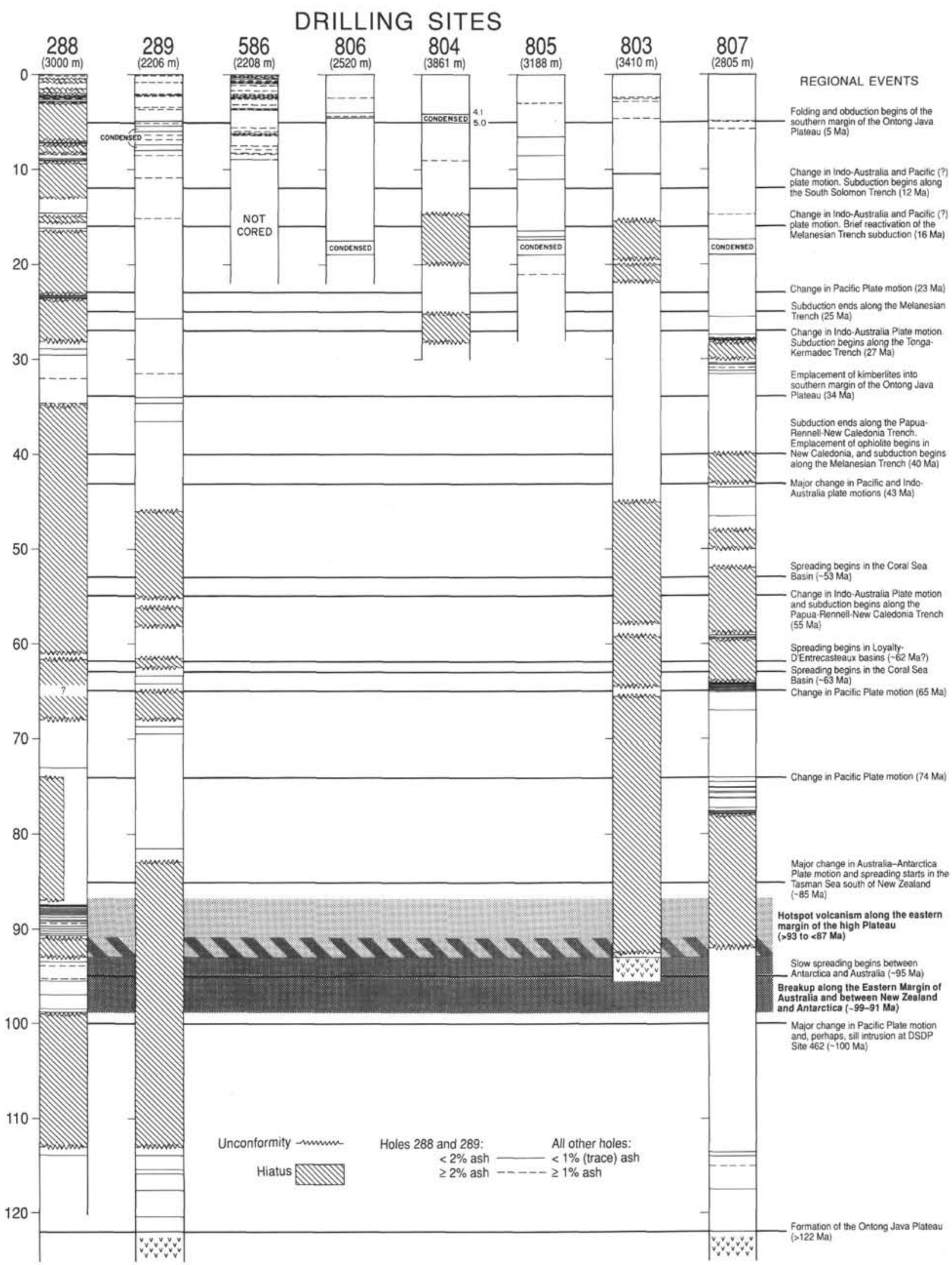

Figure 5. Composite stratigraphic occurrences of ash and unconformities at drill sites on the Ontong Java Plateau, showing changes in plate motion and regional tectono-volcanic events. 


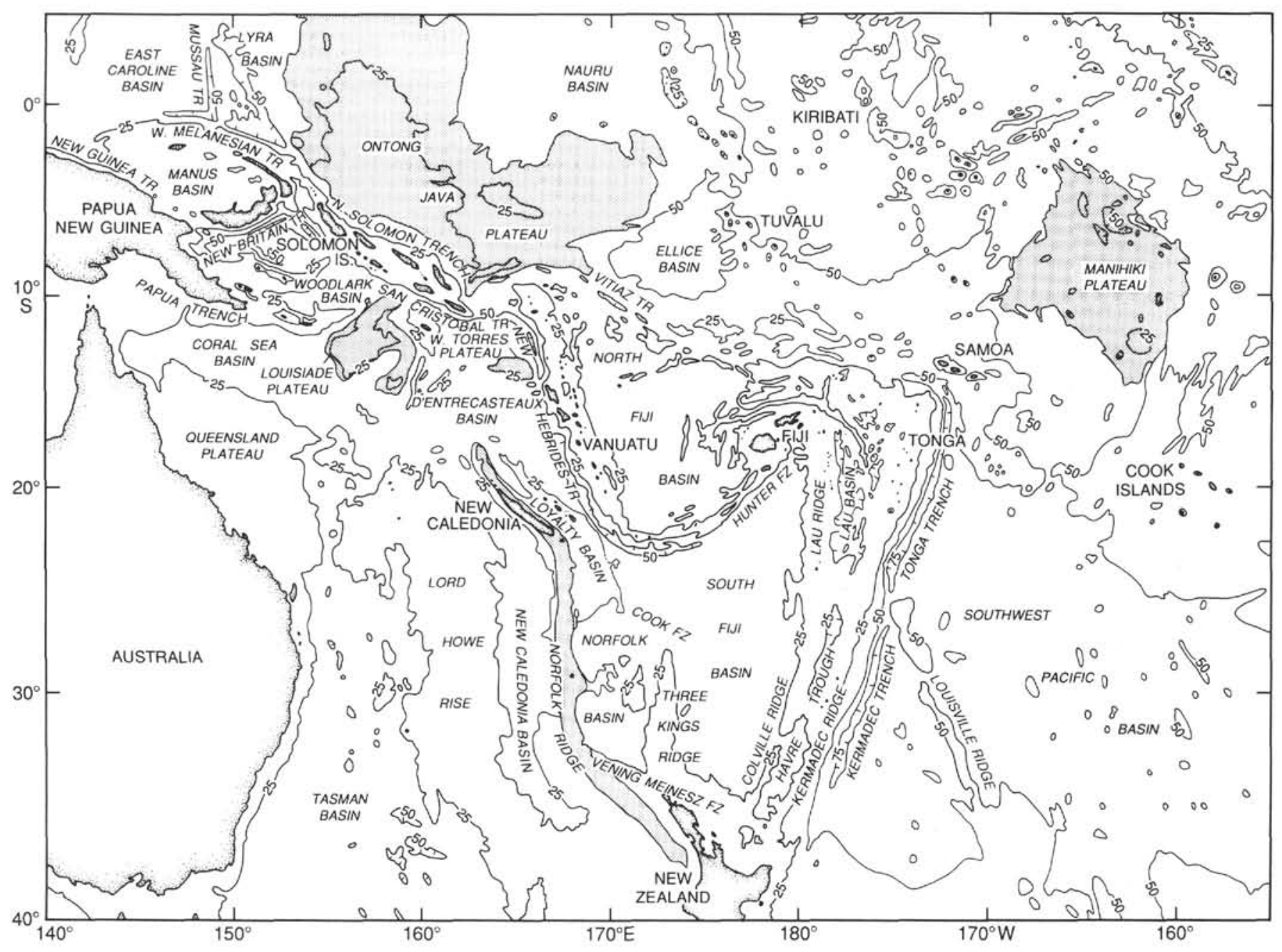

Figure 6. Location of marginal basins and tectonic elements referred to in the text.

about $55 \mathrm{Ma}$ (Yan, 1988). This event may also be concealed within hiatuses at other sites.

Between 55 and $40 \mathrm{Ma}$, convergence was occurring along the Papua-Rennell-New Caledonia subduction zone (Kroenke, 1984). Much of the record for this interval has been lost within the long-ranging upper Paleocene-lower Oligocene hiatus at DSDP Site 288, the lower-middle Eocene hiatus at DSDP Site 289, and the upper Paleocene-middle Eocene hiatus at ODP Site 803 and is only sporadically preserved at ODP Site 807. The top of the upper Paleocene-lower Eocene hiatus at ODP Site 807 may correlate with the cessation of spreading in the Coral Sea Basin at about $53 \mathrm{Ma}$. The age at the tops of the hiatuses at DSDP Site 289 and ODP Site 803 corresponds closely to the time of change in motion of the Indo-Australia and Pacific plates that occurred about $43 \mathrm{Ma}$. This was also about the time of the beginning of obduction and ophiolite emplacement in eastern Papua New Guinea (Davies, 1980).

The top of the middle Eocene hiatus at ODP Site 807 coincides with the end of subduction along the Papua-Rennell-New Caledonia subduction zone, the initiation of ophiolite emplacement in New Caledonia, and the initiation of subduction along the West Melanesian-North Solomon-Vitiaz trenches (Melanesian Trench), all of which occurred about $40 \mathrm{Ma}$. This also corresponds, in part, with widespread Hiatus PHe of Keller et al. (1987). This hiatus, however, was not observed at ODP Site 803, which is located in deeper, and thus more corrosive, water.
Between 40 and $23 \mathrm{Ma}$, the Ontong Java Plateau was obliquely converging with the Melanesian subduction zone (Kroenke, 1984). Most of the ash deposited at DSDP Sites 288 and 289 and ODP Site 807 during this time span is probably related to this convergence. Between roughly 35 and $23 \mathrm{Ma}$, the plateau may have impinged on the subduction zone. This interaction may have been responsible for the long-ranging lower Paleocene-lower Oligocene hiatus at DSDP Site 288. Some of the volcanism that occurred during this time span may also be the result of tensional rifting or cracking of the thick plateau crust as it flexed over the outer rise of the Melanesian Trench (before docking with the Melanesian Arc) (Coleman and Kroenke, 1981; Kroenke, 1984). The kimberlite intrusions that occurred about $34 \mathrm{Ma}$ (Nixon and Boyd, 1979; Nixon, 1980) may be related to this tensional rifting (Coleman and Kroenke, 1981; Kroenke, 1984). Likewise, the changes in motion of the Indo-Australia and Pacific plates that occurred between 27 and $23 \mathrm{Ma}$ (Epp, 1984; Yan, 1988) also may have had considerable tectonic impact on the margins of the Ontong Java Plateau. Hiatuses within this interval were found at DSDP Site 288 and ODP Sites 804 and 807 with ash layers overlying the hiatuses at Sites 288 and 807 . Although not observed at DSDP Site 289 and ODP Site 803, these hiatuses may be related, in part, to widespread Hiatus PHaa of Keller et al. (1987). Docking of the Ontong Java Plateau with the Melanesian Arc probably took place between 25 and $23 \mathrm{Ma}$, with subduction entirely ceasing along the Melanesian Trench by $23 \mathrm{Ma}$ (Kroenke, 1984). 
Between 23 and 10 Ma subduction was active elsewhere in the region farther away from the Ontong Java Plateau. After a period of quiescence along the Melanesian Trench, subduction was briefly reactivated between about 16 and $15 \mathrm{Ma}$, probably in response to a slight change in Indo-Australia and Pacific plate motion (Epp, 1984; Yan, 1988). This change in plate motion and reactivation of subduction is probably responsible for the lower-middle Miocene hiatuses found at DSDP Site 288 and ODP Sites 803 and 804.

Another change in Indo-Australia and perhaps Pacific plate motion took place about $12 \mathrm{Ma}$ (Epp, 1984; Yan, 1988), which probably triggered formation of the modern New Britain-San Cristobal-New Hebrides trenches (South Solomon Trench). This event may have produced the middle Miocene hiatus at DSDP Site 288, which was nearest the new subduction zone. Indeed, several hiatuses occur within the time span $12 \mathrm{Ma}$ to the present at that site. Attendant arc volcanism probably produced the ash found at all sites, generally diminishing northward. Although perhaps partly a result of dissolution, the condensed section between 5.0 and 4.1 Ma at ODP Site 804 may signal the initiation of obduction and folding of the southern edge of the Ontong Java Plateau against the Solomon Island Arc, which resulted in formation of the Malaita Anticlinorium. This condensed section correlates with an upper Miocene-upper Pliocene hiatus at DSDP Site 288, which is situated close to the deformation belt. The islands of Malaita and Ulawa were uplifted as a result of the obduction. Foraminiferal paleobathymetry and stratigraphy indicates that parts of Malaita were uplifted from mid or lower bathyal depths beginning in the late Pliocene or in the early Pleistocene (Resig et al., 1986). The aforementioned catastrophic slope failure and submarine canyon formation on the northeast margin of the Ontong Java Plateau may also be associated with this diastrophism. The mass transport associated with this event would also explain the flood of acoustically transparent sediments that have accumulated in the southwest part of the Nauru Basin (Kroenke et al., 1971). The hiatuses that occur in the upper Pliocene-lower Pleistocene and in the middle Pleistocene at Site 288 are also probably related to ongoing overthrusting associated with this tectonism.

\section{SUMMARY AND CONCLUSIONS}

All or part of the following sequence of events may have produced the hiatuses and ash horizons observed in the sections cored on the Ontong Java Plateau: (1) formation of the Ontong Java Plateau from $>122$ to $<117 \mathrm{Ma}$; (2) a major change in Pacific Plate motion at roughly $100 \mathrm{Ma}$; (3) breakup along the eastern margin of Australia and between New Zealand and Antarctica between about 98 and $91 \mathrm{Ma}$; (4) hotspot volcanism along the eastern margin of the high plateau from $>93$ to $<87 \mathrm{Ma}$; (5) initiation of slow spreading between Antarctica and Australia at about $90 \mathrm{Ma}$; (6) initiation of spreading in the Tasman Sea and south of New Zealand about $85 \mathrm{Ma}$; (7) a change in Pacific Plate motion at $74 \mathrm{Ma}$; (8) another change in Pacific Plate motion at $65 \mathrm{Ma}$; and (9) initiation of spreading in the Coral Sea Basin and possibly in the Loyalty-D'Entrecasteaux basins about $63 \mathrm{Ma}$.

The timing of events after $55 \mathrm{Ma}$ is better constrained, and the paleogeographic location of the Ontong Java Plateau is also better known. Thus, the record of many of the later events preserved in the sequences cored on the Ontong Java Plateau is probably as follows: (10) change in Indo-Australia Plate motion and beginning of subduction along the Papua-Rennell-New Caledonia trenches at about $55 \mathrm{Ma}$ and cessation of spreading in the Coral Sea Basin ( 53 Ma); (12) a major change in Pacific and Indo-Australia plate motions at about $43 \mathrm{Ma}$ and initiation of ophiolite emplacement in Papua New Guinea about $42 \mathrm{Ma}$; (13) the end of subduction along the PapuaRennell-New Caledonia trenches, initiation of ophiolite emplacement in New Caledonia, and beginning of subduction along the Melanesian Trench at $40 \mathrm{Ma}$; (14) emplacement of kimberlites into the southern margin of the Ontong Java Plateau at about $34 \mathrm{Ma}$; (15) a change in Indo-Australia Plate motion at about $27 \mathrm{Ma}$; (16) a possible change in Pacific Plate motion at about $23 \mathrm{Ma}$; (17) a change in Indo-Australia and Pacific plate motion and brief reactivation of Melanesian Trench subduction at about $16 \mathrm{Ma}$; (18) another change in Indo-Australia and Pacific(?) plate motion and initiation of subduction along the South Solomon Trench at about $12 \mathrm{Ma}$; and (19) initiation of folding and obduction of the southern margin of the Ontong Java Plateau starting about $5 \mathrm{Ma}$.

\section{ACKNOWLEDGMENTS}

Our study was aided by the technical assistance of Lillian $\mathrm{Ng}$ and Garen Ito and was supported by post-cruise funding from USSAC. Critiques by Michael Ledbetter and David Rea were extremely helpful in refining our ideas. This is University of Hawaii School of Ocean and Earth Science and Technology (SOEST) Contribution No. 2969.

\section{REFERENCES}

Andrews, J.E., Packham, G., et al., 1975. Init. Repts. DSDP, 30: Washington (U.S. Govt. Printing Office).

Barron, J.A., Keller, G., and Dunn, D.A., 1985. A multiple microfossil biochronology for the Miocene. In Kennett, J.P. (Ed.), The Miocene Ocean: Paleoceanography and Biogeography. Mem.-Geol. Soc. Am., 163:21-36.

Berger, W.H., and Johnson, T.C., 1976. Deep-sea carbonates: dissolution and mass wasting on Ontong Java Plateau. Science, 192:785-787.

Berger, W.H., Johnson, T.C., and Hamilton, E.L., 1977. Sedimentation on Ontong Java Plateau: observations on a classic "carbonate monitor." In Andersen, N.R., and Malahoff, A. (Eds.), The Fate of Fossil Fuel $\mathrm{CO}_{2}$ in the Oceans: New York (Plenum), 543-567.

Berger, W.H., Kroenke, L.W., Mayer, L.A., and Shipboard Scientific Party, 1991. Ontong Java Plateau, Leg 130: synopsis of major drilling results. In Kroenke, L.W., Berger, W.H., Janecek, T.R., et al., Proc. ODP, Init. Repts., 130: College Station, TX (Ocean Drilling Program), 497-537.

Berggren, W.A., Kent, D.V., and Flynn, J.J., 1985a. Jurassic to Paleogene: Part 2. Paleogene geochronology and chronostratigraphy. In Snelling, N.J. (Ed.), The Chronology of the Geological Record. Geol. Soc. London Mem., 10:141-195.

Berggren, W.A., Kent, D.V., and Van Couvering, J.A., 1985b. The Neogene: Part 2. Neogene geochronology and chronostratigraphy. In Snelling, N.J. (Ed.), The Chronology of the Geological Record. Geol. Soc. London Mem., 10:211-260.

Cande, S.C., LaBrecque, J.L., Larson, R.L., Pitman, III, W.C., Golovchenko, X., and Haxby, W.F. (Comps.), 1989. Magnetic Lineations of the World's Ocean Basins. AAPG LDGO Contrib. No. 4367. (Scale 1:27,400,000 at the equator, 0.16 in. per degree longitude.)

Cande, S.C., and Mutter, J.C., 1982. A revised identification of the oldest seafloor spreading anomalies between Australia and Antarctica. Earth Planet. Sci. Lett., 58:151-160.

Coleman, P.J., and Kroenke, L.W., 1981. Subduction without volcanism in the Solomon Islands arc. Geo-Mar. Lett., 1:129-134.

Davies, H.L., 1980. Crustal structure and emplacement of ophiolite in southeastern Papua New Guinea. Colloq. Int. C.N.R.S., 272:1-33.

Duncan, R.A., 1981. Hotspots in the southern oceans-an absolute frame of reference for motion of the Gondwana continents. In Solomon, S.C., Van der Voo, R., and Chinnery, M.A. (Eds.), Quantitative Methods of Assessing Plate Motions. Tectonophysics, 74:29-42.

1991. Age distribution of volcanism along aseismic ridges in the eastern Indian Ocean. In Weissel, J., Peirce, J., Taylor, E., Alt, J., et al., Proc. ODP, Sci. Results, 121: College Station, TX (Ocean Drilling Program), 507-517.

Duncan, R.A., and Clague, D.A., 1985. Pacific plate motion recorded by linear volcanic chains. In Nairn, A.E.M., Stehli, F.G., and Uyeda, S. (Eds.), The Pacific Ocean: New York (Plenum Press), 89-121.

Duncan, R.A., and McDougall, I., 1989. Plate tectonic setting. In Johnson, R.W. (Ed.), Intraplate Volcanism in Eastern Australia and New Zealand: Cambridge (Cambridge Univ. Press), 13-18.

Epp, D., 1978. Age and tectonic relationships among volcanic chains on the Pacific Plate [Ph.D. dissert.]. Univ. of Hawaii, Honolulu.

, 1984. Possible perturbations to hotspot traces and implications for the origin and structure of the Line Islands. J. Geophys. Res., 89:11273-11286.

Haq. B.U., 1991. Sequence stratigraphy, sea-level change, and significance for the deep sea. Spec. Pub. Int. Assoc. Sedimentol., 12:3-39. 
Harland, W.B., Armstrong, R.L., Cox, A.V., Craig, L.E., Smith, A.G., and Smith, D.G., 1990. A Geologic Time Scale 1989: Cambridge (Cambridge Univ. Press).

Harland, W.B., Cox, A.V., Llewellyn, P.G., Pickton, C.A.G., Smith, A.G., and Walters, R., 1982. A Geologic Time Scale: London (Cambridge Univ. Press).

Izett, G.A., Dalrymple, B., and Snee, L.W., 1991. ${ }^{40} \mathrm{Ar} /{ }^{39} \mathrm{Ar}$ Age of Cretaceous-Tertiary boundary tektites from Haiti. Science, 252:1539-1542.

Keller, G., and Barron, J.A., 1983. Paleoceanographic implications of Miocene deep-sea hiatuses. Geol. Soc. Am. Bull., 94:590-613.

, 1987. Paleodepth distribution of Neogene deep-sea hiatuses. Paleoceanography, 2:697-713.

Keller, G., Herbert, T., Dorsey, R., D'Hondt, S., Johnsson, M., and Chi, W.R., 1987. Global distribution of late Paleogene hiatuses. Geology, 15:199-203.

Kennett, J.P., 1981. Marine tephrochronology. In Emiliani, C. (Ed.), The Sea (Vol. 7): New York (Wiley), 1373-1436.

1982. Marine Geology: New York (Prentice-Hall).

Kennett, J.P., Houtz, R.E., et al., 1975. Cenozoic paleoceanography in the southwest Pacific Ocean, Antarctic glaciation and development of the Circum-Antarctic current. In Kennett, J.P., Houtz, R.E., et al., Init. Repts. DSDP, 29: Washington (U.S. Govt. Printing Office), 1155-1169.

Kennett, J.P., McBirney, A.R., and Thunell, R.C., 1977. Episodes of Cenozoic volcanism in the Circum-Pacific region. J. Volcanol. Geotherm. Res., 2:145-163.

Kennett, J.P., and Thunell, R.C., 1975. Global increase in Quaternary explosive volcanism. Science, 187:497-503.

Kennett, J.P., von der Borch, C.C., et al., 1985. Paleotectonic implications of increased late Eocene-early Oligocene volcanism from South Pacific DSDP sites. Nature, 316:507-511.

, 1986. Init. Repts. DSDP, 90, Pts. 1 and 2: Washington (U.S. Govt. Printing Office).

Klein, G.D., 1975. Depositional facies of Leg 30 Deep Sea Drilling Project sediment cores. In Andrews, J.E., Packham, G., et al., Init. Repts. DSDP, 30: Washington (U.S. Govt. Printing Office), 423-442.

Kroenke, L.W., 1972. Geology of the Ontong Java Plateau. Hawaii Inst. Geophys. Rep., No. HIG 72-5.

, 1984. Cenozoic Tectonic Development of the Southwest Pacific. U.N. ESCAP, CCOP/SOPAC, Tech. Bull., No. 6.

Kroenke, L.W., Berger, W.H., et al., 1991. Proc. ODP, Init. Repts., 130: College Station, TX (Ocean Drilling Program).

Kroenke, L.W., Moberly, R., Winterer, E.L., and Heath, G.R., 1971. In Winterer, E.L., Riedel, W.R., et al., Init. Repts. DSDP, 7, Pt. 2: Washington (U.S. Govt. Printing Office), 1161-1226.

Kyle, P.R., and Seward, D., 1984. Dispersed rhyolitic tephra from New Zealand in deep-sea sediments of the Southern Ocean. Geology, 12:487-490.

Larson, R.L., 1976. Late Jurassic and Early Cretaceous evolution of the Western Central Pacific Ocean. J. Geomagn. Geoelectr., 28:219-236.

Leg 129 Scientific Drilling Party, 1990. Jurassic oceanic crust and sediments in the Pacific, at last. Geotimes, 35:25-26.

Martini, E., 1970. Standard Paleogene calcareous nannoplankton zonation. Nature, 226:560-561.

, 1971. Standard Tertiary and Quaternary calcareous nannoplankton zonation. In Farinacci, A. (Ed.), Proc. 2nd Planktonic Conf. Roma: Rome (Ed. Technosci.), 2:739-785.

Mattinson, J.M., Kimbrough, D.L., and Bradshaw, J.Y., 1986. Western Fiordland orthogneiss: Early Cretaceous arc magmatism and granulite facies metamorphism, New Zealand. Contrib. Mineral Petrol., 92:383-392.

Mayer, L.A., Shipley, T., and Winterer, E.L., 1986. Equatorial Pacific seismic reflectors as indicators of global oceanographic events. Science, 233:761-764.
Moberly, R., Schlanger, S.O., et al., 1986. Init. Repts. DSDP, 89: Washington (U.S. Govt. Printing Office).

Molnar, P., Atwater, T., Mammerickx, J., and Smith, S.M., 1975. Magnetic anomalies, bathymetry and tectonic evolution of the South Pacific since the Late Cretaceous. Geophys. J. R. Astron. Soc., 40:383-420.

Moore, J.G., Clague, D.A., Holcomb, R.T., Lipman, P.W., Normark, W.R., and Torresan, M.E., 1989. Prodigious submarine landslides on the Hawaiian Ridge. J. Geophys. Res., 94:17465-17484.

Nixon, P.H., 1980. Kimberlites in the south-west Pacific. Nature, 287:718-720.

Nixon, P.H., and Boyd, F.R., 1979. Garnet-bearing lherzolites and discrete nodule suites from the Malaita alnoite, Solomon Islands, S.W. Pacific, and their bearing on oceanic mantle composition and geotherm. In Boyd, F.R., and Meyer, H.O.A. (Eds.), The Mantle Sample: Inclusions in Kimberlite and Other Volcanics. Proc. 2nd Int. Kimberlite Conf., Am. Geophys. Union, 2:400-423.

Rea, D.K., and Vallier, T.L., 1983. Two Cretaceous volcanic episodes in the western Pacific Ocean. Geol. Soc. Am. Bull., 94:1430-1437.

Resig. J.M., Kroenke, L.W., and Cooper, P.A., 1986. Elevation of the Pacific Province of the Solomon Islands, at the Pacific and Indo-Australian plate boundary. In Vedder, J.G., Pound, K.S., and Boundy, S.Q. (Eds.), Geology and Offshore Resources of Pacific Island Arcs-Central and Western Solomon Islands. Circum-Pac. Counc. Energy Miner. Resourc., Earth Sci. Ser., 4:261-266.

Schlanger, S.O., and Moberly, R., 1986. Sedimentary and volcanic history: east Mariana Basin and Nauru Basin. In Moberly, R., Schlanger, S.O., et al., Init. Repts. DSDP, 89: Washington (U.S. Govt. Printing Office), 653-678.

Shafik, S., 1975. Nannofossil biostratigraphy of the southwest Pacific Deep Sea Drilling Project, Leg 30. In Andrews, J.E., Packham, G., et al., Init. Repts. DSDP, 30: Washington (U.S. Govt. Printing Office), 549-598.

Shaw, R.D., 1979. On the evolution of the Tasman Sea and adjacent continental margins [Ph.D. dissert.]. Univ. of Sydney, Australia.

Sliter, W.V., 1989. Biostratigraphic zonation for Cretaceous planktonic foraminifers examined in thin section. J. Foraminiferal Res., 19:1-19.

, in press. Cretaceous planktonic foraminiferal biostratigraphy and paleoceanographic events in the Pacific Ocean with emphasis on indurated sediment. Centenary of Japanese Micropaleontology-Testimonial Volume for Dr. Yokichi Takayanagi: Tokyo (Sendai).

Theyer, F., Vincent, E., and Mayer, L.A., 1989. Sedimentation and paleoceanography of the central equatorial Pacific. In Winterer, E.L., Hussong, D.M., and Decker, R.W. (Eds.), The Eastern Pacific Ocean and Hawaii: Geol. Soc. Am., Geol. of North Am. Ser., N:347-372.

Tilling, R.1., Koyanagi, R.Y., Lipman, P.W., Lockwood, J.P., Moore, J.G., and Swanson, D.A., 1976. Earthquakes and Related Catastrophic Events, Island of Hawaii, November 29, 1975: A Preliminary Report. U.S. Geol. Surv. Circ., No. 740.

Weissel, J.K., and Watts, A.B., 1979. Tectonic evolution of the Coral Sea Basin. J. Geophys. Res., 84:4572-2582.

Winterer, E.L., Riedel, W.R., et al., 1971. Init. Repts. DSDP, 7, Pts. 1 and 2: Washington (U.S. Govt. Printing Office).

Yan, C.-Y., 1988. Indo-Australia plate motion determined from Australia and Tasman Sea hotspot trails [M.S. thesis]. Univ. of Hawaii, Hawaii Inst. of Geophysics.

Date of initial receipt: 2 December 1991

Date of acceptance: 31 August 1992

Ms 130B-050 
APPENDIX A

Legs 30 and 130 Zonal Equivalents

\begin{tabular}{|c|c|c|}
\hline \multicolumn{2}{|c|}{ Correlations * } & \multirow[b]{2}{*}{$\begin{array}{c}\text { Nannofossil zones } \\
\text { DSDP Leg } 30 \text { (Shafik, 1975) }\end{array}$} \\
\hline Age (Ma) & $\begin{array}{l}\text { Martini }(1970,1971) \\
\text { nannofossil zones }\end{array}$ & \\
\hline $0.00-0.20$ & NN21 & \multirow[t]{2}{*}{ Emiliania huxleyi - Gephyrocapsa oceanica } \\
\hline $0.20-0.50$ & NN20 & \\
\hline $0.50-2.00$ & NN19 & $\begin{array}{l}\text { Gephyrocapsa caribbeanica } \\
\text { Pseudoemiliania lacunosa }\end{array}$ \\
\hline $2.00-2.20$ & NN18 & Discoaster brouweri \\
\hline $2.20-2.40$ & NN17 & Discoaster pentaradiatus \\
\hline $2.40-3.40$ & NN16 & Discoaster tamalis \\
\hline $3.40-3.70$ & NN15 & Reticulofenestra pseudoumbilica \\
\hline $3.70-4.00$ & NN14 & \multirow[t]{2}{*}{ Ceratolithus nugosus } \\
\hline $4.00-4.50$ & NN13 & \\
\hline $4.50-5.60$ & NN12 & $\begin{aligned} \text { Ceratolithus tricomiculatus : } & \text { Ceratolithus acutus } \\
& \text { Triquetrorhabdulus rugosus }\end{aligned}$ \\
\hline $5.60-8.20$ & NN11 & Discoaster quinqueramus/D. berggrenii (lower NN11) \\
\hline $8.20-8.80$ & NN10 & Discoaster neohamatus \\
\hline $8.80-10.00$ & NN9 & $\begin{aligned} \text { Discoaster hamatus : } & \text { Catinaster calyculus } \\
& \text { Helicopontosphaera kamptneri }\end{aligned}$ \\
\hline $10.00-10.80$ & NN8 & Catinaster coalitus \\
\hline $10.80-13.10$ & NN7 & \multirow[t]{2}{*}{ Discoaster exilis } \\
\hline $13.10-14.40$ & NN6 & \\
\hline $14.40-16.20$ & NN5 & \multirow[t]{2}{*}{ Sphenolithus heteromorphus } \\
\hline $16.20-17.50$ & NN4 & \\
\hline $17.50-18.90$ & NN3 & Sphenolithus belemnos \\
\hline $18.90-23.10$ & $\mathrm{NN} 2$ & Discoaster druggii \\
\hline $23.10-23.70$ & NN1 & $\begin{array}{r}\text { Triquetrorhabdulus carinatus : Discoaster deflandrei } \\
\text { Cyclicargolithus abisectus }\end{array}$ \\
\hline $23.70-28.10$ & NP25 & Sphenolithus ciperoensis \\
\hline $28.10-30.40$ & NP24 & Sphenolithus distentus \\
\hline $30.40-34.60$ & NP23 & Sphenolithus predistentus \\
\hline $34.60-35.10$ & NP22 & Reticulofenestra hillae \\
\hline $35.10-36.90$ & NP21 & Cyclococcolithina formosa \\
\hline $36.90-37.80$ & NP19/20 & \multirow[t]{2}{*}{ Discoaster barbadiensis } \\
\hline $37.80-40.00$ & NP18 & \\
\hline
\end{tabular}


APPENDIX A (continued).

\begin{tabular}{|l|l|l|}
\hline $40.00-42.40$ & NP17 & Discoaster saipanensis \\
\hline $42.40-45.40$ & NP16 & Cyclicargolithus reticulatus - Reticulofenestra umbilica \\
\hline $45.40-50.00$ & NP15 & Chiasmolithus gigas - Nannotetrina fulgens \\
\hline $50.00-52.60$ & NP14 & Discoaster sublodoensis : Rhabdosphaera inflata \\
Discoasteroides kuepperi
\end{tabular}

- Berggren et al. (1985a, 1985b) for the Pleistocene through Eocene and Harland et al. (1990) for the Paleocene only. 


\section{APPENDIX B}

Hiatus Data

\begin{tabular}{|c|c|c|c|c|c|c|}
\hline \multicolumn{7}{|c|}{ Site 288} \\
\hline DSDP sample no. & Depth (mbsf) & Glass (\%) & Stage & Zone & Age (Ma) & Comments \\
\hline $288-1-1,140$ & 1.40 & 1 & Pleistocene & Emiliania huxleyi -Gephyrocapsa oceanica & 0.10 & \\
\hline $288-2-3,57$ & 13.57 & 1 & upper Pliocene & Gephyrocapsa caribbeanica & 2.01 & \\
\hline $288-2-3,130$ & 14.30 & 1 & upper Pliocene & Gephyrocapsa caribbeanica & 2.02 & \\
\hline $288-2-5,36$ & 16.36 & 48 & upper Pliocene & Pseudoemiliania lacunosa - Discoaster tridentatus & 2.08 & Ash layer, $11 \mathrm{~cm}$ (fine sand) \\
\hline $288-2, \mathrm{CC}$ & 19.10 & 1 & upper Pliocene & Pseudoemiliania lacunosa-Discoaster tridentatus & 2.10 & \\
\hline $288-3-0,1$ & 29.01 & 2 & upper Pliocene & Pseudoemiliania lacunosa-Discoaster tridentatus & 2.30 & \\
\hline $288-3-4,63$ & 34.63 & 1 & upper Pliocene & Pseudoemiliania lacunasa-Discoaster tridentatus & 2.40 & \\
\hline $288-3-4,74$ & 34.54 & 2 & upper Pliocene & Pseudoemiliania lacunasa-Discoaster tridentatus & 2.41 & \\
\hline 288-3-6, 105 & 37.85 & 10 & upper Pliocene & Pseudoemiliania lacunasa - Discoaster tridentatus & 2.48 & \\
\hline 288-3, CC & 38.40 & 1 & upper Pliocene & Pseudoemiliania lacunosa-Discoaster tridentatus & 2.50 & \\
\hline $288-4-1,100$ & 49.00 & 11 & upper Pliocene & Pseudoemiliania lacunasa - Discoaster tridentatus & 2.60 & Entire Core 4 (excl. CC) \\
\hline 288-5-5, 11 & 73.61 & 42 & upper Pliocene & Pseudoemiliania Lacunosa - Discoaster tridentatus & 2.95 & Ash layer, $6 \mathrm{~cm}$ \\
\hline 288-5. CC & 76.20 & 1 & upper Pliocene & Pseudoemiliania lacunasa - Discoaster tridentatus & 3.00 & \\
\hline $288-6-6,10$ & 93.80 & 60 & upper Miocene & Discoaster quinqueramus & 7.19 & Volcanic rock fragment \\
\hline $288-6-6,38$ & 94.08 & 45 & upper Miocene & Discoaster quinqueramus & 7.20 & Ash layer, $-1 \mathrm{~cm}$ \\
\hline 288-6, CC & 95.30 & 1 & upper Miocene & Discoaster neohamatus & 8.35 & \\
\hline $288 \mathrm{C}-1-1,33$ & 112.83 & 2 & upper Miocene & Discoaster hamatus (high) & 8.80 & \\
\hline $288-7-2,115$ & 117.15 & 5 & upper Miocene & Discoaster hamatus - Catinaster calyculus & 9.00 & \\
\hline 288-7, CC & 123.70 & 1 & upper Miocene & Discoaster hamatus - Catinaster calyculus & 9.10 & \\
\hline $288-10-2,110$ & 202.60 & 5 & middle Miocene & Sphenolithus heteromorphus & 14.60 & \\
\hline $288-11-2-110$ & 231.10 & 5 & lower Miocene & Sphenolithus heteromorphus & 16.20 & \\
\hline $288-11-2,111$ & 231.11 & 5 & lower Miocene & Sphenolithus heteromorphus & 16.20 & \\
\hline $288 \mathrm{~A}-1-1-35$ & 267.35 & & upper Oligocene & Triquetrorhabdulus carinatus & 23.25 & Andesite granule \\
\hline $288 \mathrm{~A}-1, \mathrm{CC}$ & 278.20 & 2 & upper Oligocene & Triquetrorhabdulus carinatus & 23.30 & \\
\hline $288 \mathrm{~A}-2-2-10$ & 306.60 & & upper Oligocene & Triquetrorhabdulus carinatus & 23.55 & Ash layer, $-5 \mathrm{~cm}$ \\
\hline $288 \mathrm{~A}-2-2,30$ & 306.80 & 4 & upper Oligocene & Triquetrorhabdulus carinatus & 23.55 & \\
\hline 288A-2, CC & 314.30 & 94 & upper Oligocene & Triquetrorhabdulus carinatus & 23.60 & Tuff, $-10 \mathrm{~cm}$ \\
\hline $288 \mathrm{~A}-3-1,133$ & 344.33 & 60 & upper Oligocene & Sphenolithus distentus & 28.80 & Tuff \\
\hline 288A-3, CC & 352.20 & 5 & upper Oligocene & Sphenolithus distentus & 29.50 & \\
\hline $288 \mathrm{~A}-4, \mathrm{CC}$ & 390.40 & 1 & upper Oligocene & Sphenolithus distentus & 32.00 & \\
\hline 288A-6, CC & 466.30 & 1 & lower Oligocene & Reticulofenestra hillae & 34.60 & \\
\hline $288 \mathrm{~A}-10, \mathrm{CC}$ & 618.12 & 5 & lower Mrastrichtian & Tetralithus trifidus & 73.00 & \\
\hline
\end{tabular}




\section{APPENDIX C}

Site Data

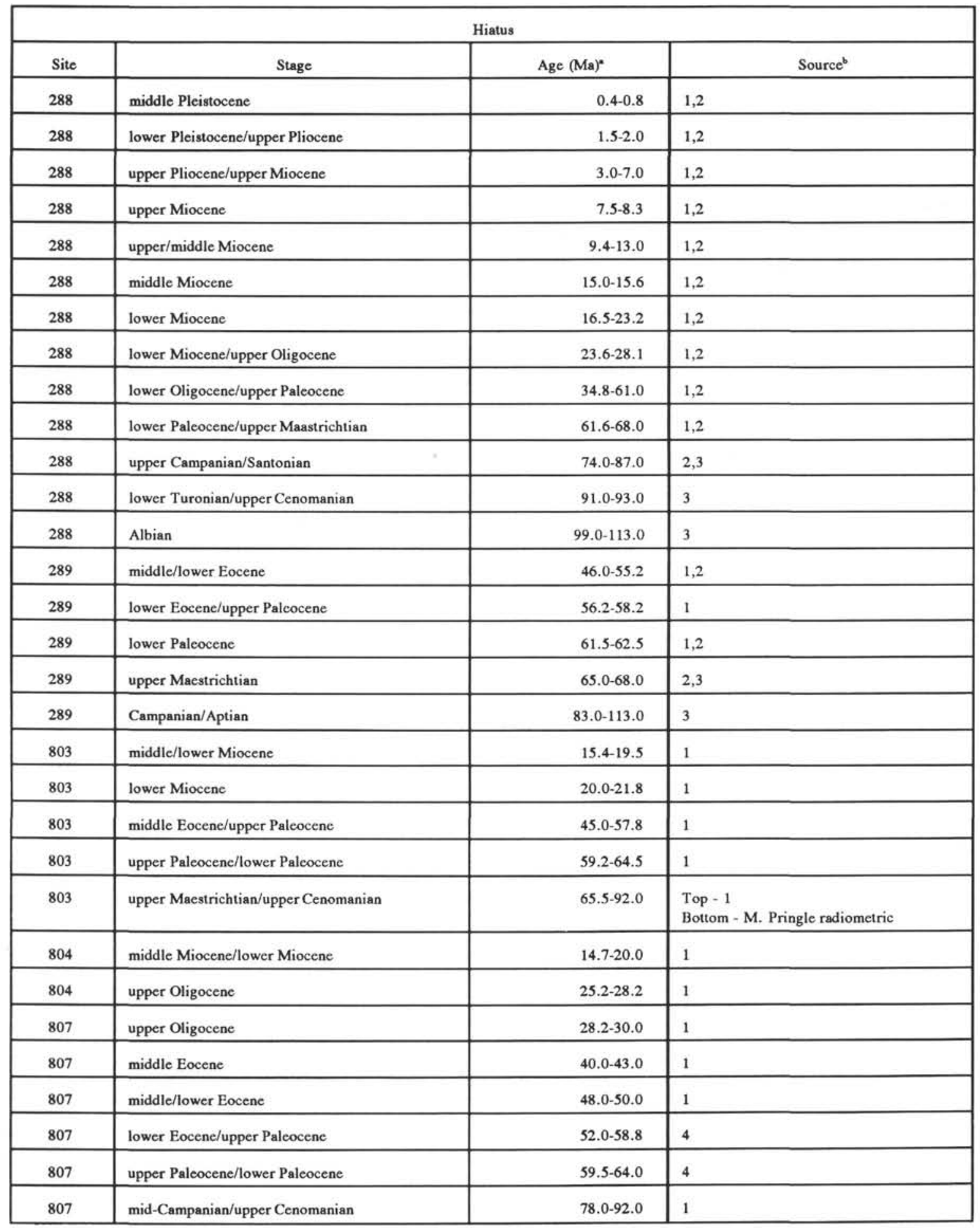


APPENDIX C (continued).

\begin{tabular}{|c|c|c|c|c|c|c|}
\hline $288 \mathrm{~A}-15-1,130$ & 743.30 & 2 & upper Coniacian & Marthasterites furcatus & 87.50 & \\
\hline $288 \mathrm{~A}-15-1,132$ & 743.32 & 2 & upper Coniacian & Marthasterites furcatus & 87.50 & \\
\hline $288 \mathrm{~A}-15-2,116$ & 744.66 & 4 & upper Coniacian & Marthasterites furcatus & 87.50 & \\
\hline 288A-15, CC & 751.30 & 15 & upper Coniacian & Marthasterites furcatus & $87.50-88.50$ & \\
\hline $288 \mathrm{~A}-16-1,50$ & 761.45 & & Coniacian & Micula decussata & $87.50-88.50$ & Ash layer (sits), $35 \mathrm{~cm}$ \\
\hline $288 \mathrm{~A}-16-1,72$ & 761.72 & 30 & Coniacian & Micula decussata & $87.50-88.50$ & Ash layer, $9.5 \mathrm{~cm}$ \\
\hline $288 \mathrm{~A}-16-1,85$ & 761.85 & & Coniacian & Micula decussata & $87.50-88.50$ & Ash layer (slts), $35 \mathrm{~cm}$ \\
\hline $288 \mathrm{~A}-16-1,96$ & 761.96 & 15 & Coniacian & Micula decussata & $87.50-88.50$ & \multirow{3}{*}{$\begin{array}{l}\text { entire core } 16 \text { (incl. CC) } \\
\text { interlaminated chalk \& ash- } \\
\text { slts to glass shard sandy slts }\end{array}$} \\
\hline $288 \mathrm{~A}-16-111$ & 762.11 & 5 & Coniacian & Micula decussata & $87.50-88.50$ & \\
\hline $288 \mathrm{~A}-16-1,131$ & 762.31 & 52 & Coniacian & Micula decussata & $87.50-88.50$ & \\
\hline $288 \mathrm{~A}-19-1,117$ & 819.17 & & upper Turonian & & $88.50-91.00$ & (25\% zeolites) \\
\hline $288 \mathrm{~A}-19-1,125$ & 819.25 & 30 & upper Turonian & & $88.50-91.00$ & Ash layer, $14 \mathrm{~cm}$ \\
\hline $288 \mathrm{~A}-20-1,121^{\circ}$ & 847.71 & 57 & Turonian & & $88.50-91.00$ & \multirow{2}{*}{$\begin{array}{l}20-1,60 \text { to } 2,70 \text { Rhythmic } \\
\text { Is/glass shard slts (ash) }\end{array}$} \\
\hline 288A-20-2, $115^{\circ}$ & 849.15 & 1 & Turonian & & $88.50-91.00$ & \\
\hline $288 \mathrm{~A}-21-2,61^{\circ}$ & 858.11 & & Turonian & & $88.50-91.00$ & $4 \%$ Plag. \\
\hline $288 \mathrm{~A}-21-2,64^{\circ}$ & 858.14 & 2 & Turonian & & $88.50-91.00$ & Rhythmic Is/ashes \\
\hline $288 \mathrm{~A}-21-2,139^{\circ}$ & 858.89 & 5 & Turonian & & $88.50-91.00$ & all of $21-1,-2, \&-3$ as above \\
\hline $288 \mathrm{~A}-22-2,49^{\circ}$ & 868.99 & 2 & Turonian & & $88.50-91.00$ & as above \\
\hline 288A-23-2-1" & 876.51 & 40 & Turonian & & $88.50-91.00$ & Interlaminated is \& altered \\
\hline 288A-23-3, 85.5 & 878.86 & 61 & middle Cenomanian & \multirow{4}{*}{$\begin{array}{l}\text { Rotalipora reicheli to } \\
\text { Dicarinella algeriana mixed assemblages" }\end{array}$} & \multirow{4}{*}{$93.00-95.50$} & glass shard slts (ash) \\
\hline $288 \mathrm{~A}-23-3,112^{\circ}$ & 879.12 & 1 & middle Cenomanian & & & all of $23-2$ \& -3 as above \\
\hline 288A-23, CC & 884.30 & 1 & middle Cenomanian & & & as above \\
\hline 288A-24-1, $0^{\circ}$ & 884.50 & & middle Cenomanian & & & 0 to 17 \\
\hline 288A-26, CC & 922.30 & 20 & lower Cenomanian & & 97.00 & \\
\hline 288A-27, CC & 941.20 & 2 & upper Albien & Eiffellithus turriseiffeli/Rotalipora appenninica & 98.50 & \\
\hline $288 \mathrm{~A}-28-1,80$ & 951.80 & 32 & upper Albian & Eiffellithus turriseiffeli/Rotalipora appenninioab & 99.00 & Ash layer \\
\hline $288 \mathrm{~A}-30-1,129$ & 980.79 & 25 & upper Aptian & Ticinella bejaouaensis" & $113.3-114.5$ & Glass shard rich $1 \mathrm{~s}, 25 \mathrm{~cm}$ \\
\hline
\end{tabular}

- All of Cores 20, 21, 22, 23 and top of Core 24 volcanic ashes and limestone are arranged in rhythmic sequences.

'Foraminifer zone determination from Sliter (in press) for Samples 288A-30-1, 81-82 cm, 288A-29, and 288A-27.

Notes: sits $=$ siltstone, $1 \mathrm{~s}=$ limestone, and plag $=$ plagioclase. 
APPENDIX C (continued).

\begin{tabular}{|c|c|c|c|c|c|c|}
\hline \multicolumn{7}{|c|}{ Site 289} \\
\hline DSDP sample no. & Depth (mbsf) & Glass (\%) & Stage & Zone & Age $(\mathrm{Ma})$ & Comments \\
\hline $289-2-1,120$ & 10.70 & 1 & Pleistocene & Emiliania huxleyi - Gephyrocapsa oceanica & 0.15 & \\
\hline $289-2-4,76$ & 14.76 & 1 & Pleistocene & Emiliania huxleyi - Gephyrocapsa oceanica & 0.20 & \\
\hline $289-2, \mathrm{CC}$ & 18.60 & 1 & Pleistocene & Gephyrocapsa caribbeanica & 0.75 & \\
\hline $289-5-1,120$ & 39.20 & 1 & upper Pliocene & Discoaster brouwert & 2.02 & \\
\hline $289-7-1,75$ & 57.75 & 2 & upper Pliocene & Discoaster brouwert & 2.17 & \\
\hline $289-7-4,75$ & 62.25 & 1 & upper Pliocene & Discoaster pentaradianus & 2.30 & \\
\hline $289-11-1,75$ & 95.75 & 1 & lower Pliocene & Reticulofenestra pseudoumbilica & 3.45 & \\
\hline 289-13, CC & 120.10 & 1 & lower Pliocene & Reticulofenestra pseudoumbilica & 3.65 & \\
\hline 289-16. CC & 151.70 & 1 & lower Pliocene & Ceratolithus tricomiculatus, $T$.rugasus $S z$ & 5.10 & \\
\hline 289-18, CC & 169.10 & 2 & upper Miocene & Discoaster quinqueramus & 6.00 & \\
\hline 289-19. CC & 180.50 & 1 & upper Miocene & Discoaster quinqueramus & 6.30 & \\
\hline 289-20, CC & 189.70 & 1 & upper Miocene & Discoaster quinqueramus & 6.80 & \\
\hline 289-30, CC & 280.10 & 1 & upper Miocene & Discoaster neohamatus & 8.50 & \\
\hline 289-37, CC & 351.50 & 1 & middle Miocene & Discoaster exilis & 10.85 & \\
\hline $289-51-1,90$ & 475.90 & 1 & middle Miocene & Sphenolithus heteromorphus & 15.10 & \\
\hline $289-82-1,75$ & 770.25 & 3 & upper Oligocene & Sphenolithus ciperoensis & 25.70 & \\
\hline $289-94-2,77$ & 885.77 & 1 & lower Oligocene & Sphenolithus predistentus & 31.50 & \\
\hline 289-99-1, 72 & 931.72 & 7 & lower Oligocene & Sphenolithus predistentus & 34.00 & \\
\hline $289-100-1,104$ & 941.54 & 5 & lower Oligocene & Reticulofenestra hillae & 34.65 & \\
\hline $289-101-1,83$ & 950.83 & & lower Oligocene & Cyclococcolithina formasa & 36.50 & Dark gray ash \\
\hline $289-121-2,84$ & 1138.34 & & lower Paleocene & Cyclocaccolithina robusta & $62.5-65.0$ & $50 \%$ Zeolite, Zeolitite \\
\hline $289-121-2,133$ & 1138.83 & & lower Paleocene & Cyclococcolithina robusta & & Zeolitite \\
\hline $289-122-2,99$ & 1147.99 & & upper Maastrichtian & Micula mura & $68.0-70.0$ & Zeolitite \\
\hline $289-122-2,128$ & 1148.28 & & upper Maastrichtian & Micula mura & & Zeolitite \\
\hline $289-131-1,48$ & 1231.48 & 30 & Campanian & Eiffellithus augustus & $80.0-83.0$ & \\
\hline $289-131-1,106$ & 1232.06 & 74 & Aptian & Ticinella bejaouaensis & $113.3-114.5$ & $\begin{array}{l}\text { Glass shard tuff } \\
80 \mathrm{~cm}\end{array}$ \\
\hline $289-131-2,12$ & 1232.62 & 10 & Aptian & Globigerinelloides algerianus & $115.0-116.0$ & \\
\hline $289-131-2,76$ & 1233.26 & 5 & Aptian & & $115.0-116.0$ & \\
\hline $289-132-2,50$ & 1261.50 & 71 & Aptian & & $117.5^{b}$ & $\begin{array}{l}\text { Glass shard tuff } \\
25 \mathrm{~cm}\end{array}$ \\
\hline $289-132-2,79$ & 1261.78 & 87 & Aptian & & $120.5^{b}$ & $\begin{array}{l}\text { Glass shard tuff } \\
13 \mathrm{~cm}\end{array}$ \\
\hline
\end{tabular}

- Foraminiferal zone determination of Stiter (in press) for Samples 131-1, 65-67 and 131-2, 16-18.

- Extrapolated from Sample 132-2, 37-40 cm, determined by Sliter (in press) as Globigerinelloides ferreolensis Zone (116.0-116.5 Ma). 
APPENDIX C (continued).

Site 586

\begin{tabular}{|c|c|c|c|c|c|c|}
\hline \multicolumn{7}{|c|}{ Site 586} \\
\hline DSDP sample no. & Depth (mbsf) & Glass (\%) & Stage & Zone & Age (Ma) & Comments \\
\hline $586-1-1,75$ & 0.75 & $<1$ & upper Pleistocene & Emiliania huxleyi $\mathrm{NN} 21$ & 0.15 & \\
\hline $586 \mathrm{~B}-1-1,23$ & 1.63 & $<1$ & upper Pleistocene & Emiliania huxleyi NN21 & 0.05 & \\
\hline $586-2-1,44$ & 1.74 & $<1$ & upper Pleistocene & Gephyrocapsa oceanica NN20 & 0.30 & \\
\hline $586-2-1,130$ & 2.60 & $<1$ & upper Pleistocene & Gephyrocapsa oceanioa NN20 & 0.40 & \\
\hline 586B-1-2, 39 & 3.29 & $<1$ & upper Pleistocene & Emiliania huxleyi $\mathrm{NN} 21$ & 0.15 & \\
\hline $586-2-2,68$ & 3.48 & 2 & upper Pleistocene & Gephyrocapsa oceanioa & 0.40 & \\
\hline $586-2-5,140$ & 8.70 & $<1$ & lower Pleistocene & sm Gephyrocapsa/P. lacunasa NN19 & 0.55 & \\
\hline $586-3-1,70$ & 11.50 & 1 & lower Pleistocene & Pseudoemiliania lacunasa NN19 & 0.60 & \\
\hline $586-3-2,51$ & 12.81 & $<1$ & lower Pleistocene & Pseudoemiliania lacunasa NN19 & 0.62 & \\
\hline 586-3-3, 91 & 14.71 & 1 & lower Pleistocene & Pseudoemiliania lacunosa NN19 & 0.65 & \\
\hline 586B-2-6, 116 & 19.66 & $<1$ & lower Pleistocene & Pseudoemiliania lacunosa NN19 & 1.10 & \\
\hline $586 \mathrm{~B}-4-3,96$ & 34.16 & $<1$ & lower Pleistocene & Pseudoemiliania lacunasa NN19 & 1.70 & \\
\hline $586 \mathrm{~A}-1-3,88$ & 43.18 & $<1$ & upper Pliowene & Discoaster brouweri (CN12d) & 2.07 & \\
\hline $586 \mathrm{~A}-2-1,75$ & 49.65 & $<1$ & upper Pliocene & Discoaster pentaradiatus $(\mathrm{CN} 12 \mathrm{c})$ & 2.20 & \\
\hline $586 \mathrm{~A}-2-2,50$ & 50.90 & $<1$ & upper Pliocene & Discoaster pentaradiatus (CN12c) & 2.22 & \\
\hline $586 \mathrm{~B}-7-1,29$ & 59.29 & $>1$ & upper Pliocene & Discoaster tamalis NN16 & 2.40 & \\
\hline $586 \mathrm{~A}-3-4,87$ & 63.87 & $<1$ & upper Pliocene & Discoaster pentaradiatus (CN12c) & 2.38 & \\
\hline $586 \mathrm{~A}-4-2,70$ & 70.30 & $<1$ & upper Pliocene & Discoaster tamalis (top $1 / 4=$ CN12b) & 2.50 & \\
\hline 586B-8-4. 59 & 73.69 & $<1$ & upper Pliocene & Discoaster tamalis NN16 & 3.20 & \\
\hline $586 \mathrm{~B}-11-1,28$ & 96.58 & $>1$ & lower Pliocene & Reticulofenestra pseudoumbilica NN15 & 3.52 & \\
\hline $586 \mathrm{~B}-11-2,67$ & 98.47 & $<1$ & lower Pliocene & Reticulofenestra pseudoumbilica $\mathrm{NN} 15$ & 3.54 & \\
\hline $586 \mathrm{~B}-11-3,114$ & 100.44 & $>1$ & lower Pliocene & Reticulofenestra pseudoumbilica NN15 & 3.56 & \\
\hline $586 \mathrm{~A}-12-4,65$ & 150.05 & $<1$ & lower Pliocene & Discoaster quinqueramus (top $1 / \mathrm{h}=\mathrm{CN} 9 \mathrm{~b})$ & 5.60 & \\
\hline $586 \mathrm{~A}-16-2,85$ & 178.05 & $<1$ & upper Miocene & Discoaster quinqueramus (top $1 / \mathrm{h}=\mathrm{CN} 9 \mathrm{~b})$ & 6.00 & \\
\hline 586B-19-5, 118 & 180.28 & $<1$ & upper Miocene & Discoaster quinqueramus (top $1 / \mathrm{h}=\mathrm{CN} 9 \mathrm{~b}$ ) & 6.25 & \\
\hline 586A-17-6, 70 & 193.50 & $<1$ & upper Miocene & Discoaster quinqueramus (top $1 / \mathrm{b}=\mathrm{CN} 9 \mathrm{~b}$ ) & 6.20 & \\
\hline $586 \mathrm{~A}-20-2,60$ & 215.10 & $<1$ & upper Miocene & Discoaster quinqueramus (top $1 \mathrm{~h}=\mathrm{CN} 9 \mathrm{~b})$ & 6.324 & \\
\hline $586 \mathrm{~A}-20-2,80$ & 215.30 & $<1$ & upper Miocene & Discoaster quinqueramus (top $1 \mathrm{~h}=\mathrm{CN} 9 \mathrm{~b})$ & 6.326 & \\
\hline 586B-24-5, 9 & 227.19 & $<1$ & upper Miocene & Discoaster quinqueramus (top $1 / 2=\mathrm{CN} 9 \mathrm{~b})$ & 7.50 & \\
\hline $586 \mathrm{~A}-23-3,20$ & 245.00 & $<1$ & upper Miocene & Discoaster quinqueramus (top $3 / \mathrm{h}=\mathrm{CN} 9 \mathrm{a})$ & 7.80 & \\
\hline 586A-27-3, 74 & 280.34 & $<1$ & upper Miocene & Discoaster neohamatus (top $1 / 2=C N 8 b)$ & 8.35 & \\
\hline 586A-27-CC, 8 & 281.25 & $<1$ & upper Miocene & Discoaster neohamatus $(\operatorname{tog} 1 / 2=C N 8 b)$ & 8.40 & \\
\hline
\end{tabular}

Note: Depths in Holes 586 and 586A from 0.89 and Depths in Hole 586B from 0.90 . 
APPENDIX C (continued).

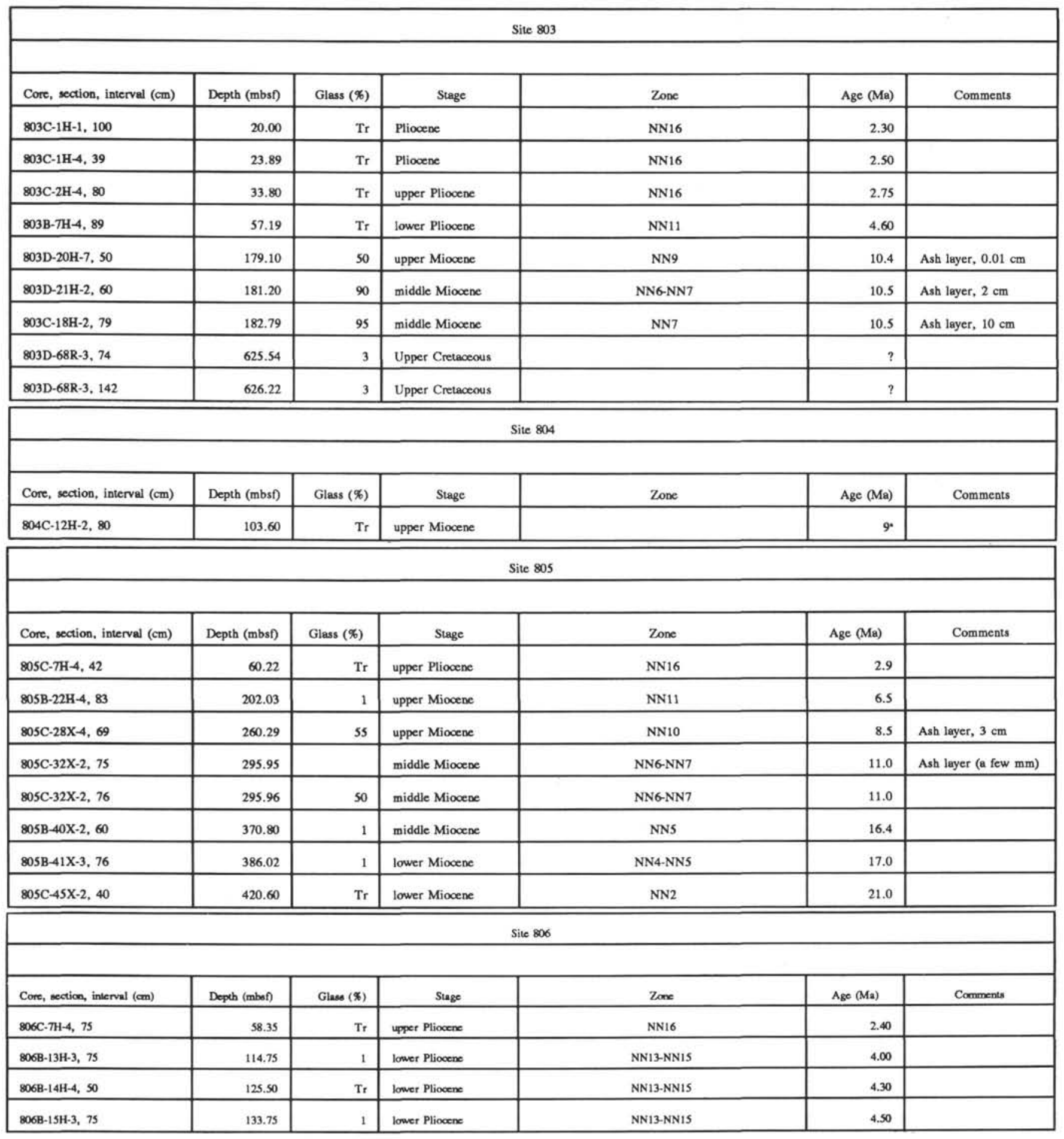

- 8-10?

Noce: $\mathrm{Tr}=$ trace. 
APPENDIX C (continued).

\begin{tabular}{|c|c|c|c|c|c|c|}
\hline \multicolumn{7}{|c|}{ Site 807} \\
\hline Core, section, interval $(\mathrm{cm})$ & Depth (mbsf) & Glass $(\%)$ & Stage & Zone & Age (Ma) & Comments \\
\hline $807 \mathrm{~B}-13 \mathrm{H}-3.74$ & 111.34 & $\mathrm{Tr}$ & lower Pliocene & $\mathrm{NN} 12$ & 4.82 & \\
\hline 807B-13H-3, 94 & 111.54 & $\mathrm{Tr}$ & lower Pliocene & $\mathrm{NN} 12$ & 4.84 & \\
\hline $807 \mathrm{~B}-17 \mathrm{H}-4,81$ & 150.91 & $\mathrm{Tr}$ & upper Miocene & NN11 & 5.73 & \\
\hline $807 \mathrm{~A}-42 \mathrm{X}-1,72$ & 389.92 & $\mathrm{Tr}$ & middle Miocene & NN5 & 14.70 & \\
\hline 807 A-67X-CC, 20 & 639.70 & & upper Oligocene & NP25 & 25.50 & Ash layer, $3 \mathrm{~cm}$ \\
\hline $807 \mathrm{~A}-70 \mathrm{X}-5,110$ & 666.33 & & upper Oligocene & NP25 & 27.30 & Ash layer, $6 \mathrm{~cm}$ \\
\hline $807 A-71 X-3,60$ & 672.50 & $\mathrm{Tr}$ & upper Oligocene & NP2S & 27.80 & \\
\hline 807A-71X-5, 70 & 675.57 & 10 & upper Oligocene & NP25 & 28.00 & Ash layer, $7 \mathrm{~cm}$ \\
\hline $807 \mathrm{~A}-72 X-2,60$ & 680.30 & 1 & upper Oligocene & NP24 & 28.10 & \\
\hline $807 \mathrm{~A}-72 \mathrm{X}-4,66$ & 683.32 & & upper Oligocene & NP24 & 28.15 & Ash layer, $3 \mathrm{~cm}$ \\
\hline $807 A-72 X-4,96$ & 683.66 & 20 & upper Oligocene & NP24 & 28.20 & Ash layer, $4 \mathrm{~cm}$ \\
\hline $807 \mathrm{~A}-73 \mathrm{X}-\mathrm{CC}, 56$ & 697.50 & & upper Oligocene & $\mathrm{NP23/24}$ & 30.40 & Ash layer, $5 \mathrm{~cm}$ \\
\hline $807 A-77 X-4,60$ & 731.60 & 5 & lower Oligocene & NP23 & 30.50 & Ash layer, $5 \mathrm{~cm}$ \\
\hline 807A-78X-3, 75 & 739.95 & $\mathrm{Tr}$ & lower Oligocene & $\mathrm{NP23}$ & 30.90 & \\
\hline $807 \mathrm{~A}-78 \mathrm{X}-5,45$ & 742.65 & 12 & lower Oligocene & $\mathrm{NP23}$ & 31.20 & Ash layer, $2 \mathrm{~cm}$ \\
\hline $807 \mathrm{~A}-80 \mathrm{X}-3,48$ & 758.71 & & lower Oligocene & NP23 & 31.60 & Ash layer, $2 \mathrm{~cm}$ \\
\hline $807 C-47 R-1,37$ & 1140.57 & 45 & middle Eocene & P12. & 43.50 & \\
\hline $807 C-47 R-1,40$ & 1140.60 & 95 & middle Eocene & P12. & 43.50 & Ash layer \\
\hline $807 \mathrm{C}-50 \mathrm{R}-1,12$ & 1155.32 & 100 & middle Eocene & $\mathrm{P} 10$ or $\mathrm{P} 11$. & $45-48$ & Ash layer, $3 \mathrm{~cm}$ \\
\hline $807 C-52 R-3,67$ & 1173.64 & & upper Paleocene & $\mathrm{P}^{\cdot} \cdot$ & $58.5-59.5$ & Ash layer, $33 \mathrm{~cm}$ \\
\hline 807C-52R-8, 89 & 1173.69 & 30 & upper Paleocene & P4. & $58.5-59.5$ & \\
\hline $807 C-53 R-4,48$ & 1184.38 & 20 & lower Paleocene & P3. & $59.5-60.5$ & \\
\hline $807 C-54 R-1,40$ & 1189.20 & & lower Paleocene & P1 $\mathrm{a}^{*}$ & $64.0-65.0$ & Ash layer, $<1 \mathrm{~cm}$ \\
\hline $807 C-54 R-1,63$ & 1189.43 & & lower Paleocene & P1 $\mathrm{a}^{*}$ & $64.0-65.0$ & Ash layer, $<1 \mathrm{~cm}$ \\
\hline $807 \mathrm{C}-54 \mathrm{R}-1,138$ & 1190.18 & & lower Paleocene & P1 $\mathrm{a}^{*}$ & $64.0-65.0$ & Ash layer, $<1 \mathrm{~cm}$ \\
\hline $807 C-54 R-2,13$ & 1190.43 & & lower Paleocene & P1 $\mathrm{a}^{*}$ & $64.0-65.0$ & Ash layer, $<1 \mathrm{~cm}$ \\
\hline $807 C-54 R-2,16$ & 1190.46 & & lower Paleocene & P1a* & $64.0-65.0$ & Ash layer, $<1 \mathrm{~cm}$ \\
\hline $807 C-54 R-2,60$ & 1190.90 & & lower Paleocene & P1a* & $64.0-65.0$ & Ash layer, $<1 \mathrm{~cm}$ \\
\hline $807 C-54 R-2,70$ & 1191.00 & & lower Paleocene & P1a: & $64.0-65.0$ & Ash layer, $<1 \mathrm{~cm}$ \\
\hline $807 C-54 R-1,83$ & 1191.13 & & lower Paleocene & P1a & $64.0-65.0$ & Ash layer, $<1 \mathrm{~cm}$ \\
\hline $807 C-54 R-2,115$ & 1191.45 & & lower Paleocene & Plat & $64.0-65.0$ & Ash layer, $<1 \mathrm{~cm}$ \\
\hline $807 C-54 R-3,34$ & 1192.07 & 5 & lower Paleocene & Ple: & $64.0-65.0$ & Ash layer, $1 \mathrm{~cm}$ \\
\hline $807 C-54 R-3,134$ & 1193.14 & & lower Paleocene & Pla: & $64.0-65.0$ & Ash layer, $1 \mathrm{~cm}$ \\
\hline $807 C-55 R-1,26$ & 1197.17 & 5 & lower Paleocene & Pla* & $64.0-65.0$ & Ash layer, $1 \mathrm{~cm}$ \\
\hline
\end{tabular}


APPENDIX C (continued).

\begin{tabular}{|c|c|c|c|c|c|}
\hline $807 C-55 R-1,87$ & 1197.77 & & upper Meastrichtian & 67.0 & Ash layer, $<1 \mathrm{~cm}$ \\
\hline $807 C-66 R-3,102$ & 1300.82 & 95 & upper Campanian & $74.0^{b}$ & Ash layer, $1 \mathrm{~cm}$ \\
\hline $807 C-69 R-3,25$ & 1332.05 & 80 & upper Campanian & $74.5^{5}$ & \\
\hline $807 \mathrm{C}-70 \mathrm{R}-3,43$ & 1341.83 & & upper Campanian & $75.0^{6}$ & Ash layer, $2 \mathrm{~cm}$ \\
\hline $807 \mathrm{C}-70 \mathrm{R}-3,64$ & 1342.04 & & upper Campanian & $75.1^{b}$ & Ash layer, $6 \mathrm{~cm}$ \\
\hline $807 \mathrm{C}-70 \mathrm{R}-3,116$ & 1342.56 & & upper Campanian & $75.5^{b}$ & Ash layer, $2 \mathrm{~cm}$ \\
\hline $807 \mathrm{C}-70 \mathrm{R}-3,123$ & 1342.63 & & upper Campanian & $75.6^{\circ}$ & Ash layer, $1 \mathrm{~cm}$ \\
\hline $807 \mathrm{C}-70 \mathrm{R}-4,19$ & 1343.09 & & upper Campanian & $76.1^{6}$ & Altered ash?, $2 \mathrm{~cm}$ \\
\hline $807 \mathrm{C}-70 \mathrm{R}-4,28$ & 1343.18 & & upper Campanian & $76.2^{b}$ & Altered ash?, $1 \mathrm{~cm}$ \\
\hline $807 C-70 R-5,15$ & 1344.55 & & upper Campanian & $77.2^{6}$ & Altered ash?, $5 \mathrm{~cm}$ \\
\hline $807 C-71 R-1,50$ & 1348.50 & & upper Campanian & $77.6^{\circ}$ & Altered ash?, $10 \mathrm{~cm}$ \\
\hline $807 C-71 R-1,95$ & 1348.95 & & upper Campanian & $77.7^{6}$ & Altered ash?, $25 \mathrm{~cm}$ \\
\hline $807 C-71 R-2,20$ & 1349.70 & & upper Campenian & $77.9^{\circ}$ & Ash layer, $10 \mathrm{~cm}$ \\
\hline $807 C-71 R-2,45$ & 1349.95 & & upper Campanian & $78.0^{\circ}$ & Ash layer, $15 \mathrm{~cm}$ \\
\hline $807 \mathrm{C}-72 \mathrm{R}-2,87$ & 1360.07 & 1 & upper Aptian & $113-114$ & \\
\hline $807 C-73 R-1,81$ & 1368.21 & 1 & upper Aptian & 114 & \\
\hline $807 C-73 R-2,98$ & 1369.88 & $\mathrm{Tr}$ & upper Aptian & 115 & \\
\hline $807 \mathrm{C}-74 \mathrm{R}-1,14$ & 1375.54 & 1 & lower Aptian & 117.5 & \\
\hline
\end{tabular}

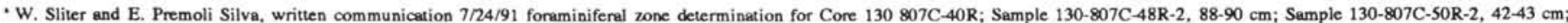
Sample 130-807C-51R-1, 3-5 cm; Sample 130-807C-51R-1, 105-107 cm; Sample 130-807C-53R-2, 65-67 cm; Sample 130-807C-53R-4, 58-60 cm; Sample 130-807C-53R-5, 10-12 cm; Sample 130-807C-54R-4, 148-149 cm; Sample 130-807C-55R-1, 26-27 cm; and Sample 130-807C-55R-1, 65-66 cm.

- Age uncertain $=$ age estimate based on a maximum age of $78 \mathrm{Ma}$ and a minimum sedimentation rate of $12.5 \mathrm{~m} / \mathrm{m} . \mathrm{y}$. for the interval $1350-1250 \mathrm{mbsf}$.

Note: $\mathrm{Tr}=$ trace. 